\title{
Emissions from Ships with respect to Their Effects on Clouds
}

\author{
Peter V. Hobbs,* Timothy J. Garrett,* Ronald J. Ferek,*@@ Scott R. Strader,* \\ Dean A. HegG, ${ }^{*}$ Glendon M. Frick, ${ }^{+}$William A. Hoppel,${ }^{+}$Richard F. Gasparovic,\# \\ Lynn M. Russell, @ Douglas W. Johnson, \& Colin O’Dowd, ** Philip A. DurkeE, ++ \\ Kurt E. NiElsen, ++ AND GeOrge InNis \#\# \\ * Department of Atmosphere Sciences, University of Washington, Seattle, Washington \\ + Naval Research Laboratory, Washington, D.C. \\ \# Applied Physics Laboratory, The Johns Hopkins University, Laurel, Maryland \\ @ California Institute of Technology, Pasadena, California \\ \& The Met. Office, Farnborough, Hampshire, United Kingdom \\ ** University of Sunderland, Sunderland United Kingdom \\ ++ Department of Meteorology, Naval Postgraduate School, Monterey, California \\ \#\# SAIC, San Diego, California
}

(Manuscript received 9 July 1996, in final form 5 August 1997)

\section{ABSTRACT}

\begin{abstract}
Emissions of particles, gases, heat, and water vapor from ships are discussed with respect to their potential for changing the microstructure of marine stratiform clouds and producing the phenomenon known as "ship tracks." Airborne measurements are used to derive emission factors of $\mathrm{SO}_{2}$ and $\mathrm{NO}$ from diesel-powered and steam turbine-powered ships, burning low-grade marine fuel oil (MFO); they were $\sim 15-89$ and $\sim 2-25 \mathrm{~g} \mathrm{~kg}^{-1}$ of fuel burned, respectively. By contrast a steam turbine-powered ship burning high-grade navy distillate fuel had an $\mathrm{SO}_{2}$ emission factor of $\sim 6 \mathrm{~g} \mathrm{~kg}^{-1}$.

Various types of ships, burning both MFO and navy distillate fuel, emitted from $\sim 4 \times 10^{15}$ to $2 \times 10^{16}$ total particles per kilogram of fuel burned $\left(\sim 4 \times 10^{15}-1.5 \times 10^{16}\right.$ particles per second). However, diesel-powered ships burning MFO emitted particles with a larger mode radius $(\sim 0.03-0.05 \mu \mathrm{m})$ and larger maximum sizes than those powered by steam turbines burning navy distillate fuel (mode radius $\sim 0.02 \mu \mathrm{m}$ ). Consequently, if the particles have similar chemical compositions, those emitted by diesel ships burning MFO will serve as cloud condensation nuclei $(\mathrm{CCN})$ at lower supersaturations (and will therefore be more likely to produce ship tracks) than the particles emitted by steam turbine ships burning distillate fuel. Since steam turbine-powered ships fueled by MFO emit particles with a mode radius similar to that of diesel-powered ships fueled by MFO, it appears that, for given ambient conditions, the type of fuel burned by a ship is more important than the type of ship engine in determining whether or not a ship will produce a ship track. However, more measurements are needed to test this hypothesis.

The particles emitted from ships appear to be primarily organics, possibly combined with sulfuric acid produced by gas-to-particle conversion of $\mathrm{SO}_{2}$. Comparison of model results with measurements in ship tracks suggests that the particles from ships contain only about $10 \%$ water-soluble materials. Measurements of the total particles entering marine stratiform clouds from diesel-powered ships fueled by MFO, and increases in droplet concentrations produced by these particles, show that only about $12 \%$ of the particles serve as CCN.

The fluxes of heat and water vapor from ships are estimated to be $\sim 2-22 \mathrm{MW}$ and $\sim 0.5-1.5 \mathrm{~kg} \mathrm{~s}^{-1}$, respectively. These emissions rarely produced measurable temperature perturbations, and never produced detectable perturbations in water vapor, in the plumes from ships. Nuclear-powered ships, which emit heat but negligible particles, do not produce ship tracks. Therefore, it is concluded that heat and water vapor emissions do not play a significant role in ship track formation and that particle emissions, particularly from those burning low-grade fuel oil, are responsible for ship track formation. Subsequent papers in this special issue discuss and test these hypotheses.
\end{abstract}

\section{Introduction}

"Ship tracks" are long-lived, linear regions of enhanced solar reflectivity in marine stratiform clouds that appear

@@Current affiliation: Office of Naval Research, Washington, D.C.

Corresponding author address: Dr. Peter V. Hobbs, Department of Atmospheric Sciences, University of Washington, Seattle, WA 98195. E-mail: phobbs@atmos.washington.edu in satellite imagery downwind of ships. An appropriate starting point for evaluating the effects of emissions from ships on clouds, and specifically on the ship track phenomenon, is to document the nature and the amounts of various types of emissions from ships vis-à-vis their effects on clouds. That is the purpose of this paper.

\section{Research platforms and experimental approach}

The facilities used to obtain in situ measurements on the emissions from the ships studied in the Monterey Area Ship Track (MAST) study were the University of 
Washington's Convair-131A (hereafter C-131A), the U.K. Meteorological Office's C-130 Hercules aircraft (hereafter C-130), and an airship operated by the Naval Research Laboratory. The C-131A was particularly well equipped to obtain measurements on the nature of the particles and gas emissions from ships and on cloud microstructures. The strength of the C-130 lay in its turbulence and radiometric measurements, and its long range. The airship was able to obtain high spatial and temporal resolution measurements of aerosol and trace gas concentrations across plumes from ships and close to the ships.

Following the identification of a ship track by satellite imagery, the two aircraft generally obtained measurements in the ship track itself. The C-131A then obtained measurements in the plume of emissions from the ship, generally following the plume upwind in order to make positive identification of the ship that was producing both the plume and the ship track. Frick and Hoppel (2000) describe how the airship was deployed.

The ship tracks that were studied formed in stratiform clouds (stratus and stratocumulus), generally several hundred meters thick located near the top of the marine boundary layer. The C-131A operated within about 250 $\mathrm{km}$ of the California coast; the C-130 studied one ship track as far as $800 \mathrm{~km}$ from the coast. The airship kept to within $140 \mathrm{~km}$ of the coast.

\section{Instrumentation}

This section contains brief descriptions of the instruments that provided data presented in this paper. More detailed descriptions of the instrumentations aboard the C-131A, the airship, and the C-130 have been given by Hobbs et al. (1991), Frick and Hoppel (1993), and Rogers et al. (1995), respectively.

\section{a. Gases}

A LI-COR Model LI-6262 $\mathrm{CO}_{2}$ analyzer was used aboard the $\mathrm{C}-131 \mathrm{~A}$ and the airship to measure $\mathrm{CO}_{2}$ concentrations. This instrument has a precision of $0.2 \mathrm{ppmv}$ at 350 ppmv. However, the measurements obtained aboard the airship attained a precision of only \pm 3 ppmv due to the method used for compensating for pressure variations.

Sulfur dioxide concentrations were measured aboard the C-131A and the airship with the pulsed-fluorescence Teco Model 43S with a precision of \pm 0.2 ppbv. Nitrogen oxides ( $\mathrm{NO}$ and $\mathrm{NO}_{x}$ ) concentrations were measured aboard the $\mathrm{C}-131 \mathrm{~A}$ with a chemiluminescence Monitor Laboratory Model $8410 \mathrm{~A}$ with a precision of $\pm 4 \mathrm{ppbv}$. Aboard the airship $\mathrm{NO}$ and $\mathrm{NO}_{x}$ were measured with a Dasibi 2108 with a precision of \pm 4 ppbv.

\section{b. Aerosols}

Continuous measurements of the total number concentrations of particles in the air [hereafter referred to as the condensation nucleus $(\mathrm{CN})$ concentration] were measured aboard the $\mathrm{C}-131 \mathrm{~A}$ and the airship with a TSI CN Model 3760 and a TSI CN Model 3022, respectively.

Aerosol size distributions were measured aboard the C-131A with three instruments. 1) A radially classified aerosol detector (RCAD), which measures the concentrations of aerosol with radii from 0.0025 to $0.1 \mu \mathrm{m}$ (Russell et al. 1996). Each size distribution had 36 channels of data and required $1 \mathrm{~min}$ for analysis as sample air was drawn from a double-bag sample. 2) Aerosols between $0.005-$ and $0.3-\mu \mathrm{m}$ radius were measured with the differential mobility particle sizer (DMPS) described by Hegg et al. (1996). 3) A Particle Measuring System (PMS) PCASP-100X provided measurements of the size distributions of particles from 0.05 - to $1.5-\mu \mathrm{m}$ radius. The first two instruments listed above sampled from dried "batch" samples of air drawn into the aircraft; the third instrument was mounted on the wing of the C-131A, but it was heated and should therefore provide measurements of the dry particle spectra.

Aboard the airship, particle size distributions from 0.005 - to $0.5-\mu \mathrm{m}$ radius were measured with an Naval Research Laboratory differential mobility analyzer, operated in a scanning mode. The aerosols were dried to a relative humidity less than $50 \%$ in cloud, and to much lower out of cloud; thus, the measured size distributions are essentially for dried aerosol. The size distributions of particles and cloud droplets from 0.25 - to $24-\mu \mathrm{m}$ radius were measured with a PMS Model CSASP-100HV scattering aerosol spectrometer.

Further information on the composition of particles emitted from the ships can be inferred from particle volatility measurements made aboard the C-130. A PMS ASASP-X optical particle counter was combined with a series of heated inlet tubes preset to specific temperatures. The system sampled ambient aerosols continuously through three heated tubes, before being sized and counted by the optical particle counter. Three temperatures were chosen: $40^{\circ} \mathrm{C}$ (to sample a dry-size ambient aerosol distribution), $150^{\circ} \mathrm{C}$ (to volatilize sulfuric acid and volatile organics), and $340^{\circ} \mathrm{C}$ (to volatilize ammonium sulfate/bisulfate) (O'Dowd and Smith 1993). Aerosol remaining at $340^{\circ} \mathrm{C}$ is typically soot carbon and/ or sea salt, which can be qualitatively distinguished through size spectral shape characteristics.

\section{c. Cloud microstructures}

The distributions of droplets between 1- and 362.5$\mu \mathrm{m}$ radius were measured with a PMS FSSP-100 and a PMS OAP-2D-C cloud probe aboard the C-131A. Corrections for coincidence and dead time losses (Baumgardner 1982; Mossop 1983) were applied to all mea- 
surements with the FSSP-100. Corrections were not made for time response and laser inhomogeneity errors (Baumgardner and Spowart 1990), since it is inappropriate to apply the currently available correction algorithm to the broad droplet size distributions typical of maritime clouds (D. Baumgardner 1994, personal communication).

The PMS OAP-2D-C records images of drops between 25 - and $362.5-\mu \mathrm{m}$ radius as they pass through a $12.5-\mu \mathrm{m}$ resolution diode array. A correction algorithm (supplied by D. Baumgardner) was applied to the data that (a) shifted the particle sizing upward by $12.5 \mu \mathrm{m}$ due to digitization errors at airspeeds greater than $\sim 50$ $\mathrm{m} \mathrm{s}^{-1}$ and (b) made corrections to the particle sample volume based on the sizes of the droplets sampled and the true aircraft speed.

Cloud interstitial aerosols were sampled with two systems on the C-131A. The first used a large "baghouse," which has a particle diameter cutoff of $\sim 6 \mu \mathrm{m}$. The second sampling system was a "no-bag" sampler, which samples only small interstitial particles $(\$ 2 \mu \mathrm{m}$ diameter), and therefore excludes most cloud hydrometers (see Hobbs et al. 1991).

Cloud liquid water content (LWC) measurements were obtained using the Gerber Scientific PVM-100A liquid water probe, and by integrating FSSP-100 volume distributions between $1-$ and $23-\mu \mathrm{m}$ radius. The PVM$100 \mathrm{~A}$ responds linearly to LWC over the droplet radius range $2-22 \mu \mathrm{m}$; however, for droplets less than $\sim 1 \mu \mathrm{m}$ and more than $\sim 35 \mu \mathrm{m}$ in radius, it underestimates LWC by more than $50 \%$ (Gerber et al. 1994). For the range of LWC encountered in marine stratiform clouds in MAST, the agreement between the integrated FSSP100 LWC and the PVM-100 LWC was generally better than 20\%. The PVM-100 (rather than the FSSP-100) was used for measuring LWC because of its faster response (10 vs $4 \mathrm{~Hz}$ for the FSSP-100). The "drizzle" LWC was derived by integrating OAP-2D-C volume distributions between $25-$ and $362.5-\mu \mathrm{m}$ radius. The OAP-2D-C does not detect droplets smaller than about $100-\mu \mathrm{m}$ radius very efficiently. Our "best estimate" of the total LWC was obtained by adding the PVM-100 and OAP-2D-C measurements.

The C-130 was equipped with a fast response $(64 \mathrm{~Hz})$ total water content probe, a Rosemount platinum resistance thermometer, and an in-cloud temperature probe that remotely senses the average air temperature by measuring an atmospheric $\mathrm{CO}_{2}$ absorption band. The latter instrument gives an average air temperature over about $50 \mathrm{~m}$ in length perpendicular to the aircraft track out of cloud, and an average over $10 \mathrm{~m}$ in cloud.

\section{Ships studied: Engines and fuels}

Tables 1 and 2 list a number of parameters for most of the ships studied in MAST for which in situ measurements were obtained. Nearly all of the commercial ships that were studied were powered by diesel engines, the exceptions were the Bremen Express, Keystone Canyon, and Sierra Madre, which have steam turbine engines. Six U.S. Navy ships were studied: USS Safeguard, which has diesel engines; the USS Kansas City and USS Mt. Vernon, which are powered by steam turbines; the gas turbine-powered USS Copeland; and the USS Truxton and USS Abraham Lincoln, which are nuclear-powered steam turbines.

The diesel-powered commercial ships (in common with most of the world's merchant shipping fleet) run on a cheap, low-grade fuel, known as marine fuel oil, which is a residual from crude oil refinement. This fuel has high density, high viscosity, high sulfur, and a high carbon residual. The U.S. Navy steam and gas turbine and diesel ships are powered by a cleaner distillate fuel, which we will refer to as navy distillate (also, known as DFM, NATO F76, or number two diesel).

Except for the Moku Pahu, Sea Pearl, and USS Safeguard, which are powered by medium-speed, fourstroke engines with a reduction gear assembly to drive the propeller shaft, all of the diesel-powered ships had low-speed, two-stroke, engines with direct coupling to the propeller shaft. The fundamental difference between diesel and other internal combustion engines is that they autoignite; that is, the fuel is not ignited by a spark but by compression in the engine cylinders. Autoignition produces high particulate emissions (Enga et al. 1982). At the beginning of a cycle of a two-stroke diesel engine, air in the cylinder is compressed by the piston as it approaches top dead center. At this point, a fine spray of fuel droplets is injected into the cylinder, whereupon the fuel droplets spontaneously ignite in the hot compressed air, increasing the cylinder pressure and driving the piston downward. Typical compression pressures are 65 to 75 bar, with maximum pressures of 80 to 90 bar. Each droplet burns down to a microscopic carbon particle, and $\mathrm{CO}_{2}$, water vapor, and heat are released by the combustion. Because the reaction is not perfectly efficient, unburned gaseous hydrocarbons are also released. Diesel combustion is relatively slow. Consequently, instead of a fuel droplet burning entirely, extended exposure of the droplet to high temperatures results in some of it evaporating. A portion of these unburned gaseous hydrocarbons condenses onto the residual carbon particles, which increase in size to $\sim 0.0005-0.005-\mu \mathrm{m}$ radius. While still in the combustion chamber, the particles aggregate to form chainlike structures from $\sim 0.005$ - to $0.05-\mu \mathrm{m}$ radius (Johnson et al. 1978). At the end of the power stroke, when work has been extracted from the gas, the exhaust valve opens and the gas cools rapidly due to expansion, and the exhaust particles undergo further agglomeration, condensation, and absorption. The final exhaust particles consist of a light and a heavy fraction (Enga et al. 1982). The heavy fraction, which predominates in the exhaust from large diesel engines, is composed of soot with absorbed heavy hydrocarbons, water, and other gaseous components. The light fraction is composed of con- 
TABLE 1. Some ships studied in MAST.*

\begin{tabular}{|c|c|c|c|c|c|c|}
\hline Ship name & Ship type & $\begin{array}{c}\text { Gross tonnage } \\
\text { or } \\
\text { displacement }\end{array}$ & $\begin{array}{c}\text { Engine type, } \\
\text { cylinders }\end{array}$ & $\begin{array}{l}\text { Length } \\
\text { (m) }\end{array}$ & $\begin{array}{c}\text { Beam } \\
(\mathrm{m})\end{array}$ & $\begin{array}{c}\text { Draft } \\
(\mathrm{m})\end{array}$ \\
\hline Axel Maersk & Container & 33400 & Diesel, 10 cyl. & 239.3 & 30.6 & 11.8 \\
\hline Bosporus Bridge & Container & 48220 & Diesel, 10 cyl. & 276.5 & 32.2 & 12.0 \\
\hline Brazilian Vitoria & Ore/oil carrier & 74139 & Diesel, 9 cyl. & 273.2 & 44.1 & 16.4 \\
\hline Cape May & Container & 42145 & Diesel, 9 cyl. & 248.1 & 32.2 & 11.5 \\
\hline Direct Kookaburra & Container & 27823 & Diesel, 6 cyl. & 227.3 & 30.6 & 10.7 \\
\hline Ever Gather & Container & 37023 & Diesel, 6 cyl. & 230.8 & 32.3 & 11.6 \\
\hline Ever Genius & Container & 37023 & Diesel, 6 cyl. & 230.8 & 32.3 & 11.6 \\
\hline Fremo Scorpius & Bulk carrier & 16569 & Diesel, 8 cyl. & 176.6 & 22.9 & 10.1 \\
\hline Gold Bond Trailblazer & Bulk carrier & 18241 & Diesel, 6 cyl. & 178.0 & 26.0 & 10.0 \\
\hline Hanjin Barcelona & Container & 50792 & Diesel, 10 cyl. & 289.5 & 32.2 & 13.0 \\
\hline Hyundai Duke & Container & 51836 & Diesel, 12 cyl. & 275.0 & 37.2 & 13.6 \\
\hline Kurama & Container & 57870 & Diesel (2), 7 cyl. & 289.5 & 32.3 & 12.2 \\
\hline Mathilde Maersk & Container & 52191 & Diesel, 10 cyl. & 294.1 & 32.3 & 13.5 \\
\hline Monterrey & Bulk carrier & 31430 & Diesel, 6 cyl. & 199.1 & 32.2 & 12.2 \\
\hline Newport Bridge & Container & 48220 & Diesel, 10 cyl. & 276.5 & 32.3 & 12.0 \\
\hline NYK Sunrise & Container & 43209 & Diesel, 9 cyl. & 251.5 & 32.2 & 11.5 \\
\hline $\mathrm{Pu} \mathrm{He}$ & Container & 35963 & Diesel, 6 cyl. & 236.1 & 32.3 & 12.0 \\
\hline Samuel H. Armacost & Tanker & 21582 & Diesel, 6 cyl. & 179.2 & 30.4 & 11.0 \\
\hline Sanko Peace & Bulk carrier & 16605 & Diesel, 6 cyl. & 168.3 & 26.0 & 9.8 \\
\hline Skaugran & Roll-on/-off carrier & 28137 & Diesel, 8 cyl. & 182.5 & 32.3 & 10.3 \\
\hline Star Livorno & Bulk carrier & 26964 & Diesel, 4 cyl. & 186.5 & 30.1 & 11.9 \\
\hline Tai He & Container & 35963 & Diesel, 6 cyl. & 236.1 & 32.2 & 12.0 \\
\hline Toluca & Bulk carrier & 31340 & Diesel, 6 cyl. & 198.9 & 32.2 & 12.2 \\
\hline Моки Раһи & Pusher tug & n.a. & Diesel (2), 14 cyl. & n.a. & 25.0 & 11.9 \\
\hline Sea Pearl & Bulk carrier & 23569 & Diesel (2), 16 cyl. & 184.2 & 28.3 & 10.8 \\
\hline USS Safeguard & Salvage ship & $2880 * *$ & Diesel (4) & 77.7 & 15.5 & 5.2 \\
\hline Bremen Express & Container & 57803 & Steam turbine & 287.6 & 32.3 & 12.8 \\
\hline Keystone Canyon & Tanker & 81776 & Steam turbine & 260.8 & 52.7 & 14.5 \\
\hline Sierra Madre & Tanker & 21351 & Steam turbine & 200.7 & 30.5 & 10.7 \\
\hline USS Kansas City & Oiler & $41350 * *$ & Steam turbine & 200.9 & 29.3 & 10.2 \\
\hline USS Mt. Vernon & Dock landing ship & $13700 * *$ & Steam turbine & 168.6 & 25.6 & 6.0 \\
\hline USS Copeland & Frigate & $3638 * *$ & Gas turbine & 135.1 & 13.7 & 4.5 \\
\hline USS Truxtun & Cruiser & $9127 * *$ & Nuclear, steam turbine & 171.9 & 17.7 & 9.4 \\
\hline USS Abraham Lincoln & Aircraft carrier & $102000 * *$ & Nuclear, steam turbine & 332.9 & 40.8 & 11.9 \\
\hline Unidentified ship & Container & n.a. & n.a. & n.a. & n.a. & n.a. \\
\hline
\end{tabular}

* N.a. indicates information not available.

** Full load displacement (in tons).

densed hydrocarbons (with or without water) and sulfate.

In a steam turbine engine the fuel is combusted at higher temperatures than in diesel engines. Consequently, the fuel burns faster and more completely in a steam turbine engine, and there are less unburned gaseous hydrocarbons available to recondense on the residual carbon particles in the exhaust.

Gas turbines require fuels very low in incombustible components, such as silica and metal elements, in order to avoid corrosion of the turbine blades. Similarly, sulfur must be kept to a minimum because it promotes hot section corrosion (sulfidation). Gas turbines operate with a large quantity of excess air, and as a result the conversion of carbon to $\mathrm{CO}_{2}$ is almost complete. The production of $\mathrm{NO}_{x}$ can be large, however. The efficiency of gas turbine engines is directly related to the turbine inlet temperature, and methods of lowering the $\mathrm{NO}_{x}$ emissions (such as water or steam injection) increase the production of $\mathrm{CO}$ and hydrocarbons.

Of course, little if any particles or gas emissions are expected from the engines of nuclear-powered ships.

\section{Methods for estimating fluxes and emission factors of particles and gases from ships}

\section{a. Carbon dioxide balance}

The principal carbon by-product of fossil fuel combustion is $\mathrm{CO}_{2}(\mathrm{CO}$ and unburned hydrocarbons are also present in the exhausts from combustion engines, but these contribute only a small fraction of the total mass of carbon). Measurements made aboard the C-131A showed that the excess concentrations of $\mathrm{CN}\left(\right.$ and $\mathrm{SO}_{2}$ ) in the plumes from diesel-powered ships were generally well correlated with the excess concentrations of $\mathrm{CO}_{2}$ 
TABLE 2. Propulsion system parameters for some of the ships studied in MAST. ${ }^{a}$

\begin{tabular}{|c|c|c|c|c|c|c|c|}
\hline Ship name & $\begin{array}{l}\text { Rated } \\
\text { power } \\
(\mathrm{MW})^{\mathrm{b}}\end{array}$ & $\begin{array}{c}\text { Observed } \\
\text { power } \\
(\mathrm{MW})^{\mathrm{c}}\end{array}$ & Fuel type ${ }^{\mathrm{d}}$ & $\begin{array}{l}\text { Estimated } \\
\text { fuel } \\
\text { consump- } \\
\text { tion } \\
\left(\mathrm{kg} \mathrm{s}^{-1}\right)^{\mathrm{e}}\end{array}$ & $\begin{array}{l}\text { Speed } \\
\left(\mathrm{m} \mathrm{s}^{-1}\right)^{\mathrm{f}}\end{array}$ & $\begin{array}{l}\text { Overall } \\
\text { effi- } \\
\text { ciency } \\
(\%)^{\mathrm{g}}\end{array}$ & $\begin{array}{c}\text { Stack } \\
\text { heat } \\
\text { flux } \\
(\mathrm{MW})^{\mathrm{h}}\end{array}$ \\
\hline Axel Maersk & 29.1 & 25.4 & Marine fuel oil & $1.46^{\mathrm{j}}$ & 11.8 & 41 & 18 \\
\hline Bosporus Bridge & 36.0 & 30.9 & Marine fuel oil & 1.41 & 12.2 & 52 & 14 \\
\hline Brazilian Vitoria & 21.5 & $19.3^{\mathrm{i}}$ & n.a. & $1.01^{\mathrm{k}}$ & 6.7 & 45 & 12 \\
\hline Cape May & 21.7 & 21.7 & Marine fuel oil & 1.03 & 10.7 & 50 & 11 \\
\hline Direct Kookaburra & 14.5 & 12.3 & Marine fuel oil & 0.60 & 8.8 & 48 & 6.5 \\
\hline Ever Gather & 17.9 & 16.1 & Marine fuel oil & $0.84^{\mathrm{k}}$ & 8.3 & 45 & 10 \\
\hline Ever Genius & 17.9 & 9.8 & Marine fuel oil & $0.60^{\mathrm{k}}$ & 8.4 & 45 & 7 \\
\hline Fremo Scorpius & 7.1 & $6.4^{\mathrm{i}}$ & n.a. & $0.32^{\mathrm{k}}$ & $7.7^{1}$ & 46 & 3.5 \\
\hline Gold Bond Trailblazer & 6.7 & 5.2 & Marine fuel oil & 0.26 & 6.7 & 46 & 3 \\
\hline Hanjin Barcelona & 39.0 & $35.1^{\mathrm{i}}$ & n.a. & 1.63 & 11.9 & 51 & 17 \\
\hline Hyundai Duke & 50.0 & $45.0^{\mathrm{i}}$ & n.a. & 2.05 & 13.4 & 52 & 21 \\
\hline Kurama & 41.2 & 36.5 & Marine fuel oil & 1.66 & 10.9 & 52 & 17 \\
\hline Mathilde Maersk & 34.0 & 34.0 & Marine fuel oil & 1.55 & 11.8 & 52 & 16 \\
\hline Monterrey & 16.4 & $14.8^{\mathrm{i}}$ & Marine fuel oil & 0.70 & 8.8 & 50 & 7.5 \\
\hline Newport Bridge & 31.0 & 21.6 & n.a. & $1.02^{\mathrm{j}}$ & 11.5 & 50 & 11 \\
\hline NYK Sunrise & 30.2 & $27.2^{\mathrm{i}}$ & n.a. & 1.26 & $12.0^{1}$ & 51 & 13 \\
\hline $\mathrm{Pu} \mathrm{He}$ & 17.0 & $15.3^{\mathrm{i}}$ & n.a. & 0.70 & $9.8^{1}$ & 52 & 7 \\
\hline Samuel H. Armacost & 8.5 & 6.9 & Marine fuel oil & 0.34 & 5.7 & 48 & 4 \\
\hline Sanko Peace & 5.6 & 5.0 & Marine fuel oil & 0.22 & 6.6 & 53 & 2 \\
\hline Skaugran & 11.1 & $10.0^{\mathrm{i}}$ & n.a. & 0.56 & $7.6^{1}$ & 42 & 7 \\
\hline Star Livorno & 10.0 & $9.0^{\mathrm{i}}$ & Marine fuel oil & 0.46 & 7.0 & 46 & 5 \\
\hline Tai He & 17.0 & $15.3^{\mathrm{i}}$ & n.a. & $0.72^{\mathrm{j}}$ & 9.0 & 50 & 8 \\
\hline Toluca & 16.5 & $14.8^{\mathrm{i}}$ & n.a. & 0.70 & n.a. & 50 & 7.5 \\
\hline Moku Pahu & 10.4 & 7.5 & Marine fuel oil & 0.43 & 7.0 & 41 & 5.5 \\
\hline Sea Pearl & 11.9 & $10.7^{\mathrm{i}}$ & Marine fuel oil & $0.60^{\mathrm{k}}$ & 7.6 & 42 & 7.5 \\
\hline USS Safeguard & 3.1 & 2.8 & Navy distillate & 0.16 & 6.7 & 41 & 2.1 \\
\hline Bremen Express & 29.8 & 11.8 & Marine fuel oil & 1.07 & 8.7 & 26 & 16.8 \\
\hline Keystone Canyon & 19.9 & 8.8 & n.a. & $0.61^{\mathrm{j}}$ & 4.6 & 34 & 10.5 \\
\hline Sierra Madre & 9.7 & $8.7^{\mathrm{i}}$ & n.a. & $0.68^{j}$ & $8.0^{1}$ & 30 & 10 \\
\hline USS Kansas City (upwind) & 23.9 & $21.5^{\mathrm{i}}$ & Navy distillate & 1.52 & 9.0 & 33 & 22 \\
\hline USS Kansas City (downwind) & & 8.2 & & 0.58 & $6-9$ & 33 & 0.5 \\
\hline USS Mt. Vernon (27 Jun 1994) & 17.9 & 4.0 & Navy distillate & 0.29 & 5 & 33 & 4 \\
\hline USS Mt. Vernon (28 Jun 1994) & & $16.1^{\mathrm{i}}$ & & 1.14 & 8.7 & 33 & 16 \\
\hline USS Copeland & 30.6 & 6.4 & Navy distillate & 0.51 & $8.4-11.3$ & 29 & 15.5 \\
\hline USS Truxtun & 52.2 & n.a. & Nuclear & n.a. & 12 & n.a. & n.a. \\
\hline USS Abraham Lincoln & 193.9 & n.a. & Nuclear & n.a. & n.a. & n.a. & n.a. \\
\hline Unidentified ship & n.a. & n.a. & n.a. & n.a. & 11.3 & n.a. & n.a. \\
\hline
\end{tabular}

${ }^{a}$ N.a. indicates information not available.

${ }^{\mathrm{b}}$ Propulsion output is shaft/brake output for turbine/diesel engine, respectively.

${ }^{\mathrm{c}}$ Estimated from ship log entries for engine power, engine RPM, or vessel speed, except as noted.

${ }^{\mathrm{d}}$ Marine fuel oil comes in a variety of types.

${ }^{\mathrm{e}}$ Estimated from power output and nominal engine specific fuel consumption, except as noted.

${ }^{\mathrm{f}}$ Value from ship logs or radio contacts, except as noted.

g Given by input power/observed power.

${ }^{\mathrm{h}}$ For diesel and steam turbine engines it is assumed that $50 \%$ of the waste heat goes into the stack. Therefore, stack heat flux $=50 / 100$ (fuel consumption in $\left.\mathrm{kg} \mathrm{s}^{-1}\right)\left(4.2 \times 10^{7} \mathrm{~J} \mathrm{~kg}^{-1}\right)(1-$ engine efficiency). For gas turbine engines it is assumed that all of waste heat goes into stack.

${ }^{\text {i }}$ Estimated assuming operation at $90 \%$ of maximum continuous output power.

${ }^{j}$ Estimated from power output and specific fuel consumption in log entry.

${ }^{\mathrm{k}}$ Estimated from power output and specific fuel consumption in Lloyds Registry of Ships.

${ }^{1}$ Maximum sustained operating speed from Lloyds Registry of Ships.

(Fig. 1). Since the only likely source for the perturbations in $\mathrm{CO}_{2}$ is combustion, it is clear that the high concentrations of particles (and $\mathrm{SO}_{2}$ ) observed downwind of the ships originated from the ships. Using the measured (linear) correlations between $\mathrm{CN}$ and $\mathrm{CO}_{2}$ (and $\mathrm{SO}_{2}$ and $\mathrm{CO}_{2}$ ) in ship plumes, estimates of the fluxes of $\mathrm{CN}$ (and $\mathrm{SO}_{2}$ ) from a ship can be derived from the $\mathrm{CO}_{2}$ flux.

The mass flux of $\mathrm{CO}_{2}$ from a ship's engine can be obtained from the rate of fuel consumption and the stoi- 

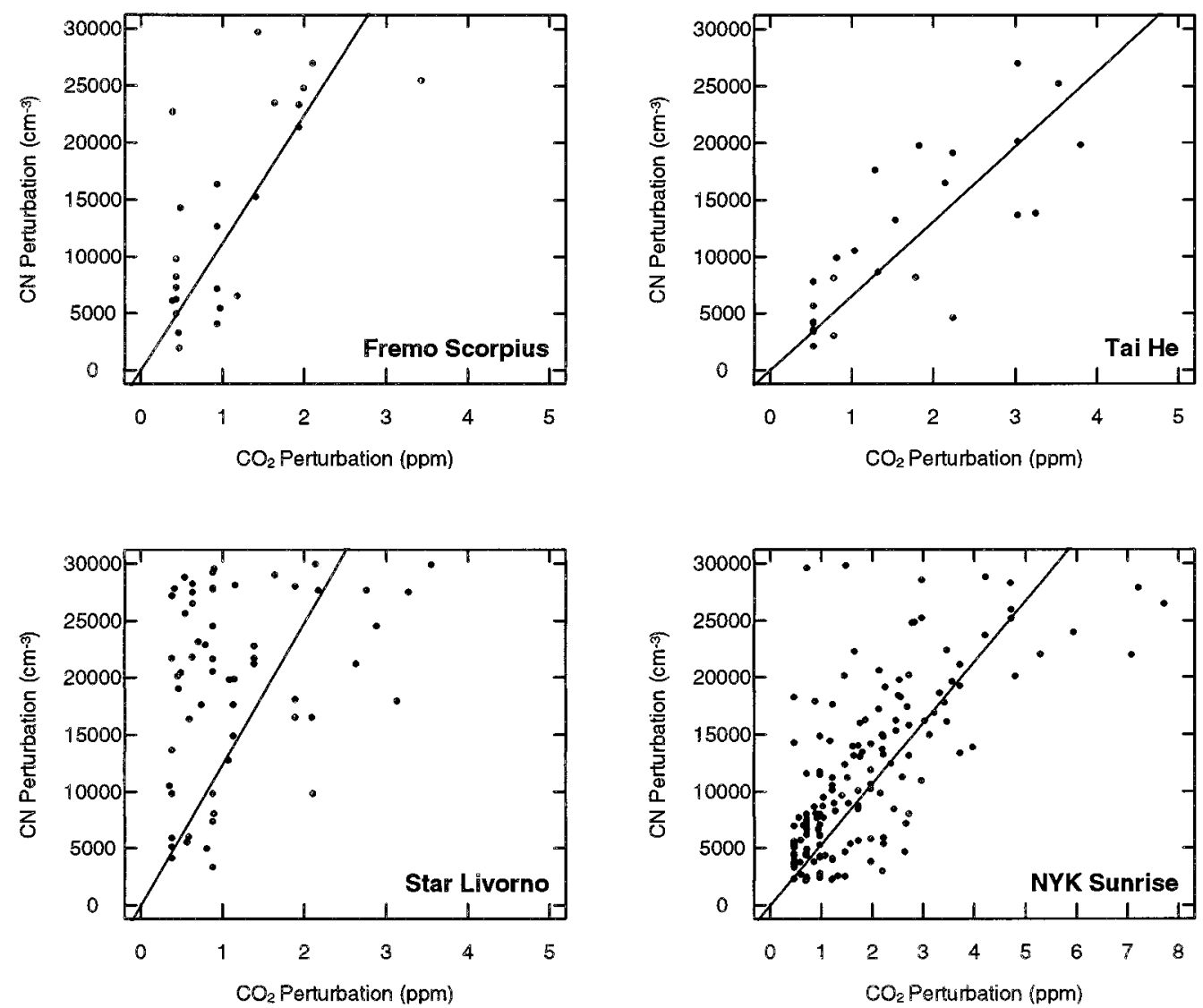

Fig. 1. Measurements from the $\mathrm{C}-131 \mathrm{~A}$ of perturbations from ambient values of condensation nucleus (CN) concentrations vs perturbations from ambient $\mathrm{CO}_{2}$ concentrations in the plumes from four ships. The lines represent linear least squares fits to the data.

chiometry of the combustion reaction. For marine fuel oil, which, as noted previously, is generally burned in large marine diesel engines, the ratio of the number of hydrogen to carbon atoms is 1.8 (Tuttle 1995). An ideal combustion reaction burns fuel in the diesel engines of a ship with an average stoichiometry given by

$$
C_{x} H_{y}+\left(x+\frac{y}{4}\right) \mathrm{O}_{2}=x \mathrm{CO}_{2}+\frac{y}{2} \mathrm{H}_{2} \mathrm{O},
$$

where $y / x=1.8$. Thus, the ratio of the mass of $\mathrm{CO}_{2}$ produced by reaction (1) to the mass of $\mathrm{C}_{x} \mathrm{H}_{y}$ consumed is 3.2. Therefore, the mass flux of $\mathrm{CO}_{2}$ from a dieselpowered merchant ship is 3.2 times the fuel consumption rate (fuel consumption rates are given in Table 2).

The slope of the least squares linear regression of $\mathrm{CN}$ to $\mathrm{CO}_{2}$, divided by the air density and the mass ratio of $\mathrm{CO}_{2}$ to $\mathrm{C}_{x} \mathrm{H}_{y}$ (3.2), yields the amount of $\mathrm{CN}$ emitted by a ship per unit mass of marine fuel oil burned (we call this quantity the $\mathrm{CN}$ emission factor). The emission factors of $\mathrm{SO}_{2}$ (and $\mathrm{NO}_{x}$ ) were calculated from the ratios of the total $\mathrm{SO}_{2}$ to the $\mathrm{CN}$ (and $\mathrm{NO}_{x}$ to $\mathrm{CN}$ ) in a plume. The product of the emission factor of a species and the fuel consumption rate yields the mass flux of the species from the ship.

\section{b. Gaussian plume model}

Estimates of the fluxes (in $\mathrm{kg} \mathrm{s}^{-1}$ ) of $\mathrm{CN}$ and $\mathrm{SO}_{2}$ from the Sea Pearl, Bremen Express, USS Mt. Vernon, and an unidentified ship were derived from measurements made aboard the airship during transects of the plumes of effluents at distances of several kilometers from the ships. These measurements were used in a nonreactive Gaussian plume model, with reflecting boundaries at the surface and the top of the marine boundary layer, to calculate source strengths. Details of the model are given by Frick and Hoppel (2000).

In view of the fewer approximations inherent in the carbon dioxide balance method compared to the Gaussian plume model, the emission factors and fluxes derived from the former technique are considered to be more reliable.

Close to the ships, the plumes of effluent were about $0.5-1.5 \mathrm{~km}$ across. Further downwind in the clouds, the ship plumes were about $1-5 \mathrm{~km}$ across. 


\section{Results}

a. Fluxes and emission factors of particles and gases from ships

Measurements made aboard the C-131A were used to estimate fluxes and emission factors of particles and gases from the steam turbine-powered USS Mt. Vernon (burning navy distillate) and from the diesel-powered Moku Pahu, Fremo Scorpius, Brazilian Vitoria, Tai He, Star Livorno, and NYK Sunrise (all burning marine fuel oil). Measurements from the airship were used to estimate fluxes and emission factors from the diesel-powered Sea Pearl (burning marine fuel oil), the steam turbine-powered Bremen Express (burning marine fuel oil), and the USS Mt. Vernon. Results derived from the carbon dioxide balance method are shown in Table 3.

The derived emission factors for $\mathrm{SO}_{2}$ and $\mathrm{NO}$ for the diesel-powered and steam turbine-powered ships burning low-grade marine fuel oil range from 15 to 89 and 2 to $25 \mathrm{~g} \mathrm{~kg}^{-1}$, respectively. However, for the steam turbine-powered USS Mt. Vernon, which burned navy distillate fuel, the $\mathrm{SO}_{2}$ emission factor was only $6 \mathrm{~g}$ $\mathrm{kg}^{-1}$.

Multiplication of the emission factors given in Table 3 by the rate of fuel consumption of the respective ship (see Table 2) yields fluxes. The ranges of fluxes, derived in this way, for $\mathrm{SO}_{2}$ and $\mathrm{NO}$ from the diesel- and steam turbine-powered ships burning marine fuel oil were 1541 and $1-18 \mathrm{~g} \mathrm{~s}^{-1}$, respectively. For the USS Mt. Vernon the derived fluxes of $\mathrm{SO}_{2}$ were $6.8 \mathrm{~g} \mathrm{~s}^{-1}$ on 27 June 1994 and $1.7 \mathrm{~g} \mathrm{~s}^{-1}$ on 28 June 1994.

Shown in Table 4 are the fluxes of $\mathrm{SO}_{2}$, derived from measurements made aboard the airship using the Gauss- ian plume model, for the USS Mt. Vernon, the Bremen Express, the Sea Pearl, and the unidentified ship. They range from 3 to $12 \mathrm{~g} \mathrm{~s}^{-1}$. It should be noted that the flux depends not only on the emission factor but also on the fuel consumption rate. Also, the plume method assumes the airship passed through the plume at the altitude of maximum concentration, which was not usually the case. Also, the Gaussian plume model represents an average condition.

If it is assumed that all of the sulfur emissions from ships are in the form of $\mathrm{SO}_{2}$, the ratio of the flux of sulfur $\left(\right.$ as $\mathrm{SO}_{2}$ ) to the fuel consumption rate gives the fuel sulfur content. The range of fuel sulfur contents derived in this way is $\sim 0.3 \%-4.5 \%$ (by weight), which is typical of the sulfur contents of ship fuels.

The CN fluxes for the diesel-powered and steam turbine-powered ships burning marine fuel oil and distillate fuel given in Table $3\left(4 \times 10^{15}-1.5 \times 10^{16}\right.$ particles per second) are similar to those given in Table $4(2 \times$ $\left.10^{15}-10^{16} \mathrm{~s}^{-1}\right)$. Clearly, ships are a highly concentrated source of particle emissions, which are often emitted into quite clean marine environments.

\section{b. Intensities of emissions}

Following the emissions of particles and gases from a ship, the effluents are diluted in the horizontal by the wind relative to the ship, and in the vertical by mixing through the depth of the boundary layer. Under uniform and steady-state conditions, these effects can be taken into account by defining the intensity $\left(I_{X}\right)$ of a pollutant $X$ as

$$
I_{X} \equiv \frac{\text { Flux of } X \text { from ship }}{\text { (Average speed of ship relative to wind)(Average depth of boundary layer) }}
$$

The units of $I_{X}$ are mass of $X$ (or, if $X$ refers to particles, it could be number of particles) per unit area, where the unit area is on a vertical plane (or curtain) parallel to the wind direction.

An amount $I_{X}$ of a pollutant is available over every square meter of the curtain for dispersion perpendicular to the direction of the wind. If we assume that the distribution of a pollutant across the width of a plume is Gaussian, and the boundary of the plume is taken to be the location where the concentration of $X$ is $\exp (-1)$ of the peak concentration of $X$ (at the center of the plume), then $84.3 \%[=\operatorname{erf}(1) / \operatorname{erf}(\infty)]$ of $X$ will lie within the plume boundaries. Hence, the average concentration of $X$ across a plume where the width is $w$ is

$$
\bar{X}=\frac{0.843 I_{X}}{w} \text {. }
$$

\section{c. Particle emissions from ships and comparisons with particles in ship tracks}

The method described in section $6 \mathrm{~b}$ was used to estimate the increases (above ambient) in the total number of particles $\left(\Delta N_{\mathrm{CN}}\right)$ in the air just below cloud base produced by the emissions from several of the ships that were studied. When these particles enter a layer of stratiform cloud in the boundary layer, they either serve as cloud condensation nuclei (CCN) and form cloud droplets, or they reside as interstitial particles between the cloud droplets. Since both cloud droplet and interstitial aerosol concentrations were measured aboard the C-131A during traverses of ship tracks and ambient cloud, we can compare our estimates of $\Delta N_{\mathrm{CN}}$ with $\Delta N_{\text {tot }}$, where $\Delta N_{\text {tot }}$ is the sum of the increases (above 


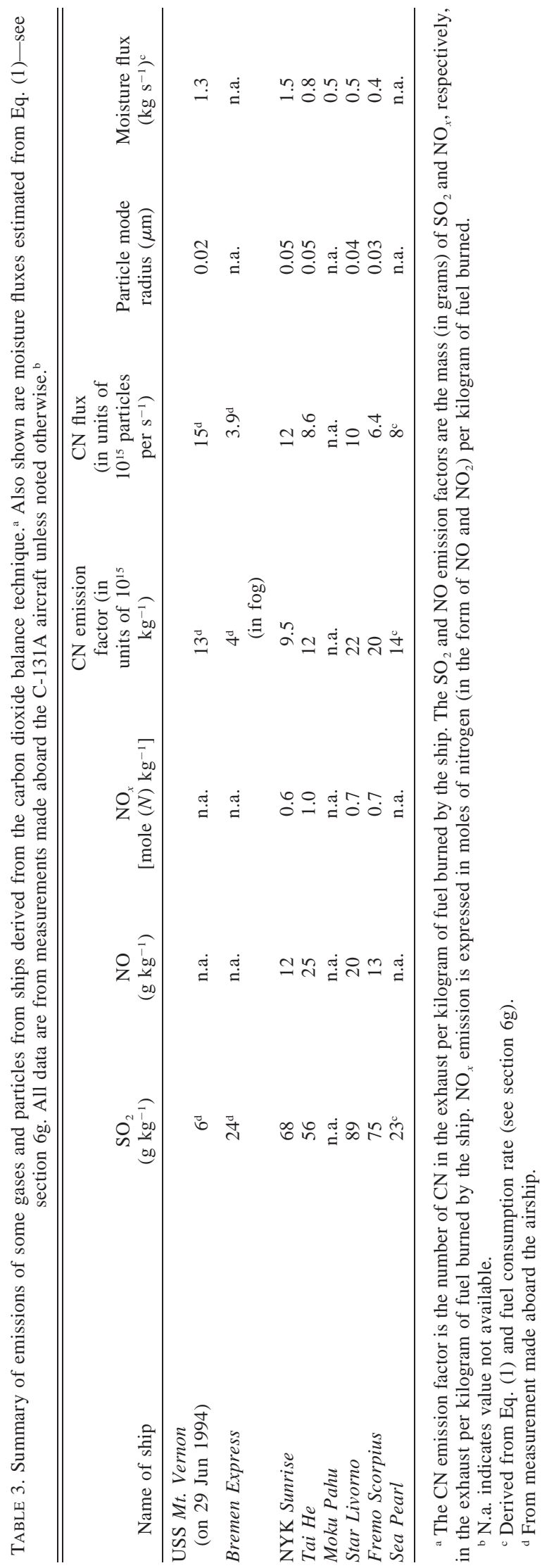



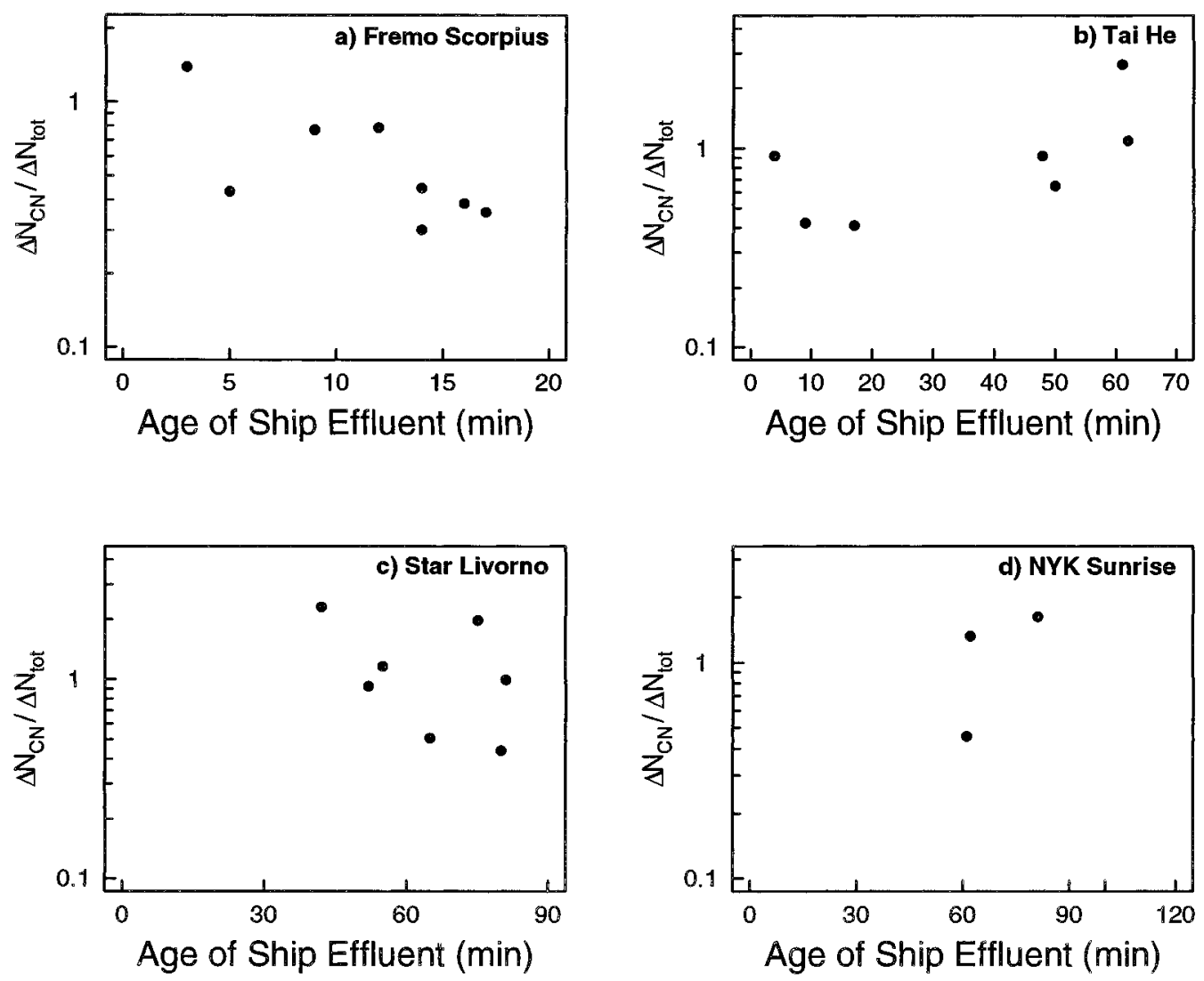

FIG. 2. Predicted increases in $\mathrm{CN}$ concentrations at cloud base $\left(\Delta N_{\mathrm{CN}}\right)$ divided by measured increases in total cloud particle concentrations $\left(\Delta N_{\text {tot }}=\Delta N_{\text {drops }}+\Delta N_{\text {interstitial particles }}\right)$ vs age of ship effluent. Condensation nucleus measurements are $1-\mathrm{Hz}$ averages from the TSI $3760 \mathrm{CN}$ counter, and droplet concentrations are 4-Hz averages from the PMS FSSP-100, aboard the C-131A.

ambient) of cloud droplet and cloud interstitial aerosol concentrations in a ship track.

Shown in Fig. 2 are values of $\Delta N_{\mathrm{CN}} / \Delta N_{\text {tot }}$ versus the age of the ship effluent for four diesel-powered ships. ${ }^{1}$ The mean values of $\Delta N_{\mathrm{CN}} / \Delta N_{\text {tot }}$ for the Fremo Scorpius, Tai He, Star Livorno, and NYK Sunrise are 0.6, 1.0, 1.0 , and 1.1 (for an overall average of 0.9 ). In view of the uncertainties inherent in estimating $\Delta N_{\mathrm{CN}}$, the derived values of $\Delta N_{\mathrm{CN}} / \Delta N_{\text {tot }}$ are considered to be sufficiently close to unity to confirm that the increases in total particle concentrations in the ship tracks were due to ship effluents.

The fraction of the $\mathrm{CN}$ in the plume from a ship that are activated as CCN is given by $\Delta N_{d} / \Delta N_{\text {tot }}$, where $\Delta N_{d}$ in the increase (above ambient) in drop concentrations in the ship track. These ratios, for the Fremo Scorpius, Tai He, Star Livorno, and NYK Sunrise, are shown in Fig. 3. The percentages of $\mathrm{CN}$ from the ships that served as $\mathrm{CCN}$, and therefore became droplets in the ship

\footnotetext{
${ }^{1}$ The age of a parcel of ship effluent is the time elapsed since the parcel left the ship. Such ages were calculated using the advection scheme described by Tessmer (1996).
}

tracks, were $4 \pm 1,8 \pm 6,18 \pm 7$, and $17 \pm 8$ for the Fremo Scorpius, Tai He, Star Livorno, and NYK Sunrise, respectively. For comparison, in laboratory experiments Hallett et al. (1989) found that 10\%-20\% of the combustion aerosol from a diesel-gasoline mixture served as $\mathrm{CCN}$ at $1 \%$ supersaturation. Supersaturations in ship tracks in stratiform clouds are expected to be less than $1 \%$. Therefore, lower percentages of combustion aerosol should be activated as $\mathrm{CCN}$ in the ship tracks we studied than were measured by Hallett et al.

TABLE 4. Source strengths of $\mathrm{CN}$ and $\mathrm{SO}_{2}$ from four ships derived from measurements aboard the airship using the Gaussian plume model. The \pm values are standard deviations from the mean determined from four passes through each plume.

\begin{tabular}{lcc}
\hline \hline & & \begin{tabular}{c}
$\mathrm{CN}$ (in units \\
of $10^{15}$ \\
particles \\
\multicolumn{1}{c}{ Ship }
\end{tabular} \\
$\begin{array}{ccc}\mathrm{SO}_{2} \\
\left(\mathrm{~g} \mathrm{~s}^{-1}\right)\end{array}$ & \\
\hline USS Mt. Vernon & & \\
$\quad$ (on 29 Jun 1994) & $3 \pm 1.5$ & $7.5 \pm 5$ \\
Bremen Express & $12 \pm 2$ & $2 \pm 1$ \\
Sea Pearl & $9.5 \pm 0.5$ & $5 \pm 1.5$ \\
Unidentified ship & $5 \pm 3$ & $10 \pm 3$ \\
\hline
\end{tabular}



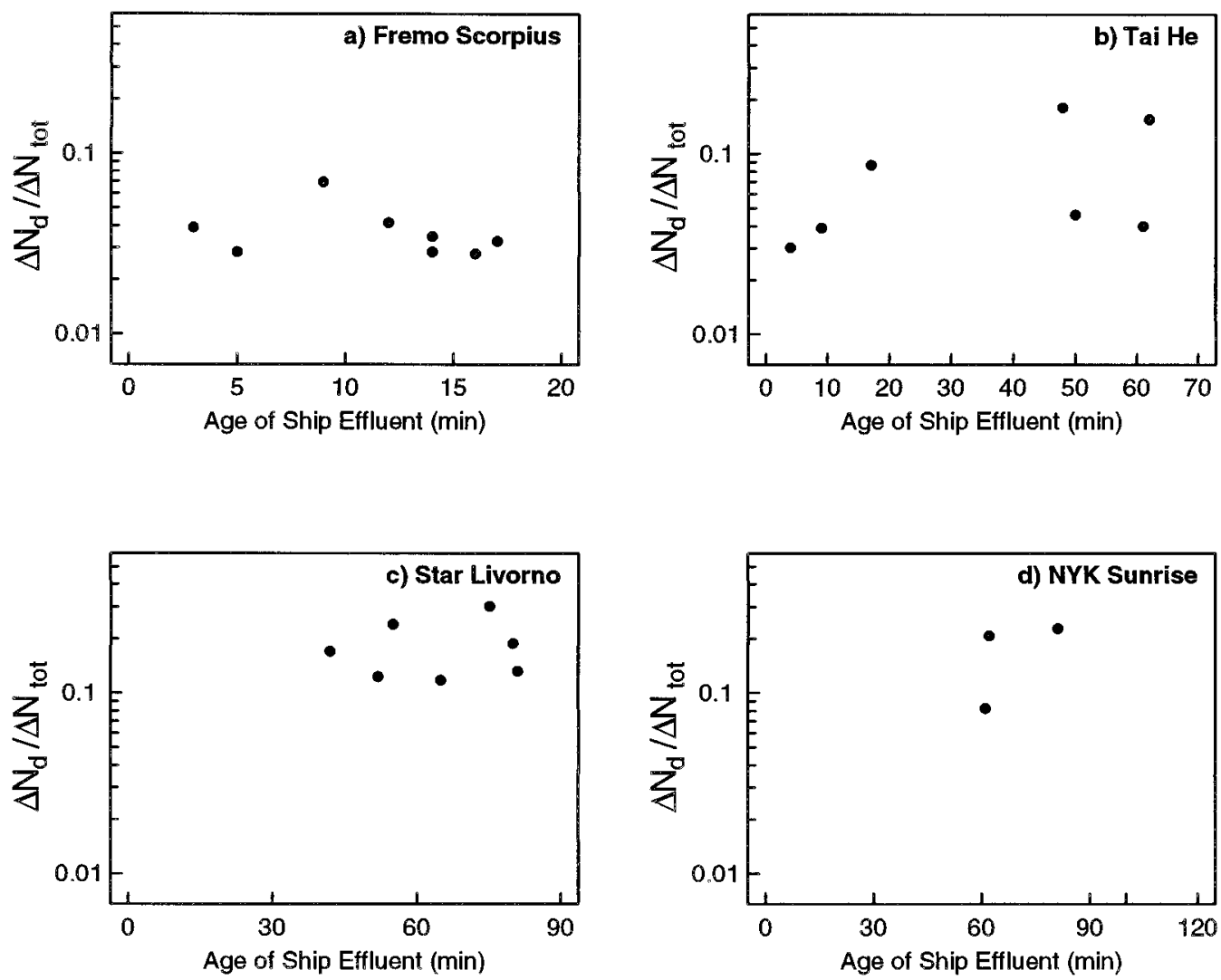

FIG. 3. Measured increases in cloud droplet concentrations in ship tracks $\left(\Delta N_{d}\right)$ divided by increase in total cloud particle concentrations in ship track $\left(\Delta N_{\text {tot }}=\Delta N_{\text {drops }}+\Delta N_{\text {interstitial particles }}\right) . \Delta N_{d} / \Delta N_{\text {tot }}$ is therefore the fraction of CN in a ship's plume that acted as CCN in the cloud. Droplet concentrations are 4-Hz averages from the FSSP-100, and $\mathrm{CN}$ concentrations are $1-\mathrm{Hz}$ averages from the TSI 3760 counter, aboard the $\mathrm{C}-131 \mathrm{~A}$.

For the diesel-powered Fremo Scorpius, Tai He, Star Livorno, and NYK Sunrise, the percentages of CN that served as $\mathrm{CCN}$ in the stratiform clouds studied ranged from $4 \%$ to $18 \%$. Therefore, since the average $\mathrm{CN}$ flux from these four ships was $\sim 10^{16} \mathrm{~s}^{-1}$ (derived from values given in Table 3), the average effective flux of $\mathrm{CCN}$ was about $10^{15} \mathrm{~s}^{-1}$. Although large, this flux is between 2 and 4 orders of magnitude less than fluxes of CCN at a nominal $1 \%$ supersaturation reported by Hobbs et al. (1970) and Eagan et al. (1974) for large Kraft paper mills $\left(\sim 10^{19}\right.$ and $4 \times 10^{17} \mathrm{~s}^{-1}$, respectively), by Hobbs et al. (1980) for coal-fired power plants $\left(\sim 10^{17} \mathrm{~s}^{-1}\right)$, and by Frisbie and Hudson (1993) for the city of Denver $\left(1.7 \times 10^{17} \mathrm{~s}^{-1}\right)$. Again, however, it must be noted that our derived flux for ships is for $\mathrm{CCN}$ active in marine stratiform clouds, which have supersaturations considerably less than $1 \%$.

\section{d. Particle size distributions}

Examples of particle size distributions measured in the plumes from various ships, and in the ambient air on either side of these plumes, are shown in Figs. 4-6. The measurements shown in these figures were obtained using different instruments and from two platforms (the $\mathrm{C}-131 \mathrm{~A}$ and the airship). The various measurements are generally consistent and therefore lead to similar conclusions, which are summarized below.

The ships emitted particles with a marked nucleation mode ( $\sim 0.01-0.1 \mu \mathrm{m}$ radius), but with negligible numbers of particles with radii greater than about $0.1 \mu \mathrm{m}$. The steam turbine-powered USS Mt. Vernon, burning navy distillate fuel, emitted smaller particles than the diesel-powered ships burning marine fuel oil. For example, it can be seen from Fig. 4 that the radius of the peak concentration in the nucleation mode (the mode radius) is $0.02 \mu \mathrm{m}$ for the USS Mt. Vernon, compared to $0.045 \mu \mathrm{m}$ for the diesel-powered Tai He and NYK Sunrise, $0.035 \mu \mathrm{m}$ for the diesel-powered Star Livorno, and $0.03 \mu \mathrm{m}$ for the diesel-powered Fremo Scorpius, which burned marine fuel oil (Fig. 4). This dichotomy is reflected in both the smaller particle sizes at the peak concentration, and the smaller maximum sizes of the particles, emitted by the USS Mt. Vernon compared to the other four ships. Thus, the USS Mt. Vernon produced few particles larger than $0.05-\mu \mathrm{m}$ radius, while the diesel-powered ships produced few particles larger than $0.1-\mu \mathrm{m}$ radius. Consequently, for similar aerosol com- 

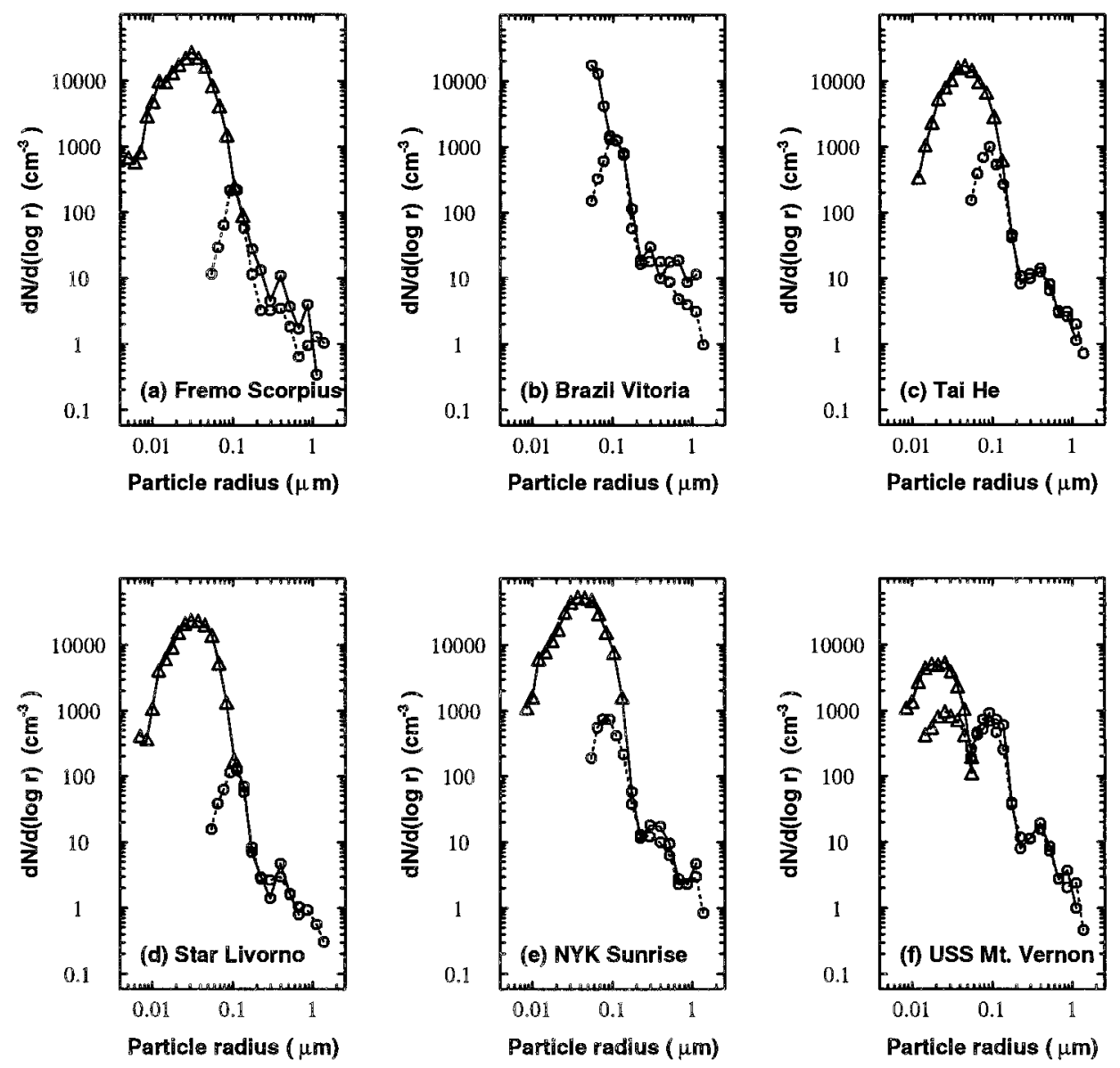

FIG. 4. Particle size spectra measured from the C-131A in noncloudy air in the plumes from six of the case study ships (triangles and solid lines) and in the adjacent ambient air (circles and dashed lines). Except for the USS Mt. Vernon, which is a steam-powered turbine, all of the ships are diesel powered. For the Brazilian Vitoria, Tai He, and USS Mt. Vernon the passes were across the widths of the plumes at distances of $4,<1$, and $<1 \mathrm{~km}$, respectively, from the ships. For the Fremo Scorpius, Star Livorno, and NYK Sunrise the passes were along the lengths of the plumes as the aircraft flew close to the plume centerlines from 6,8 , and $10 \mathrm{~km}$, respectively, from the ships up to within $1 \mathrm{~km}$ from the ships. DMPS measurements (triangles) are from bag samples exposed in the plumes from the ships. PCASP measurements (circles) in the plume are 4-Hz averages from measurements taken during the period of the bag sample and $4-\mathrm{Hz}$ averages over $\sim 3$ min for the ambient air samples. In the case of the Brazilian Vitoria (where the DMPS failed) the PCASP particle spectra are averaged over $1 \mathrm{~s}$ in the center of the plume.

position, the particles emitted by the steam turbinepowered USS Mt. Vernon, burning navy distillate fuel, would require larger supersaturations to act as $\mathrm{CCN}$ than the particles emitted by the diesel-powered ships burning marine fuel oil. This deduction was confirmed by the fact that significant increases in droplet concentrations were not observed in stratiform clouds that intercepted emissions from either the steam turbine-powered USS Mt. Vernon and USS Kansas City or the gas turbine-powered USS Copeland, all three of which used the same high-grade navy distillate fuel. In contrast, the diesel-powered ships using marine fuel oil, which emitted larger particles, produced ship tracks (compare Figs. 7 and 8). Also, as shown in section 6c, particles from the diesel-powered ships were found to account quantitatively for the increases in droplet concentrations ob- served in the ship tracks they produced, even though on average, only about $12 \%$ of the particles in the plumes from these ships served as CCN.

As expected, compared to other ships, the emissions from the nuclear-powered USS Abraham Lincoln produced only small perturbations in the ambient particle size distributions. These perturbations were probably produced by auxiliary power-generating units on the ship. Nuclear-powered ships were not observed to produce ship tracks.

\section{e. Estimation of the soluble fraction of particles in ship emissions}

The ambient particle size distributions shown in Figs. 4-6 are typical of those observed in clean marine bound- 

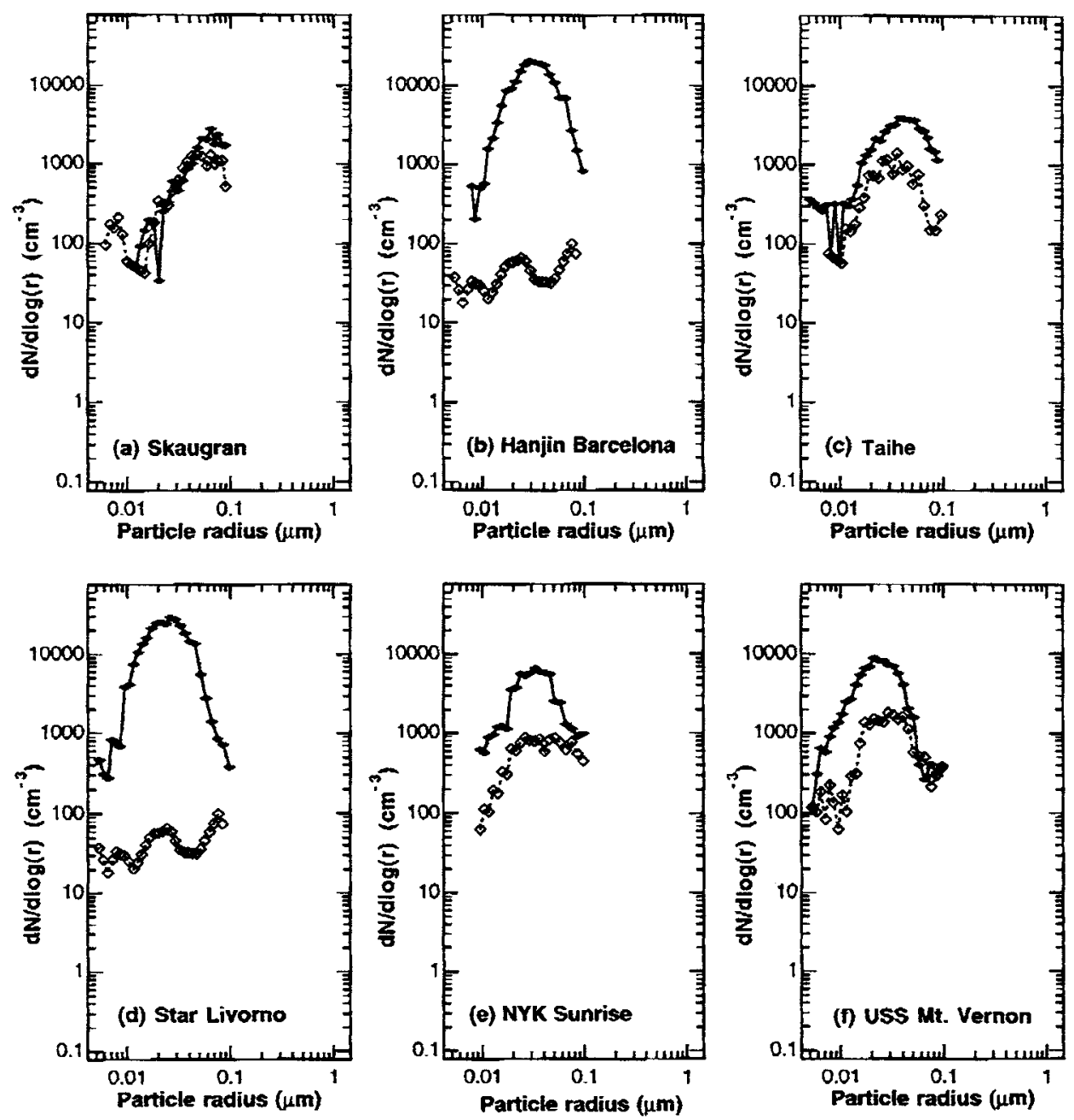

FIG. 5. Particle size spectra measured from the C-131A aircraft in noncloudy air in the plumes from six of the case study ships (closed diamonds) and in the adjacent ambient air (open diamonds). The measurements were made with the RCAD. Except for the USS Mt. Vernon, which is a steam-powered turbine, all of the ships are diesel powered. (a) The plume of the Skaugran was measured at 1123:55 LT on 11 Jun. (b) The Hanjin Barcelona was sampled at 1351:22 LT on 29 Jun. (c) The Tai He was sampled on 27 Jun at 5.7 $\mathrm{km}$ from the ship at 1339:02 LT. (d) The Star Livorno plume size distribution was measured at $1.4 \mathrm{~km}$ from the ship at 1407:59 LT on 29 Jun. (e) The NYK Sunrise was measured at $3.3 \mathrm{~km}$ from the ship at 1528: 16 LT on 30 Jun. (f) The USS Mount Vernon was sampled at 1434:15 LT on 27 Jun.

ary layer air (e.g., Hoppel et al. 1990; Garrett and Hobbs 1995). The size distributions are bimodal, with peaks at $\sim 0.02-0.03-$ and $\sim 0.1-\mu \mathrm{m}$ radius (e.g., Fig. 6 ). The valley between the two modes indicates the minimum size of the background aerosol that was activated as $\mathrm{CCN}$ and, subsequently, underwent cloud processing to produce the second (larger-sized) mode.

The bimodal size distributions measured below cloud bases in ambient air contain information on the effective cloud supersaturation and droplet concentrations in the stratiform clouds above; namely, the minimum between the modes is related to the maximum effective supersaturation, and the number of particles under the residue mode is related to the number of cloud droplets (Hoppel et al. 1986). Measurements within the cloud gives the cloud droplet spectrum and cloud liquid water. It is possible to input the aerosol size distribution measured below cloud into a simple adiabatic cloud parcel model with explicit cloud microphysics, and determine the expansion rate (related to the effective updraft velocity) necessary to activate all particles under the cloud residue mode, and to determine the duration of the expansion (related to cloud height) required to yield the observed liquid water content of the cloud. The effective updraft velocity and duration determined for the plume-free region are then assumed to characterize the essential dynamics as they affect cloud microphysics both in and outside a ship's plume (i.e., the dynamics, but not the cloud microphysics, are assumed to remain the same inside and outside the plume). The composition of the 

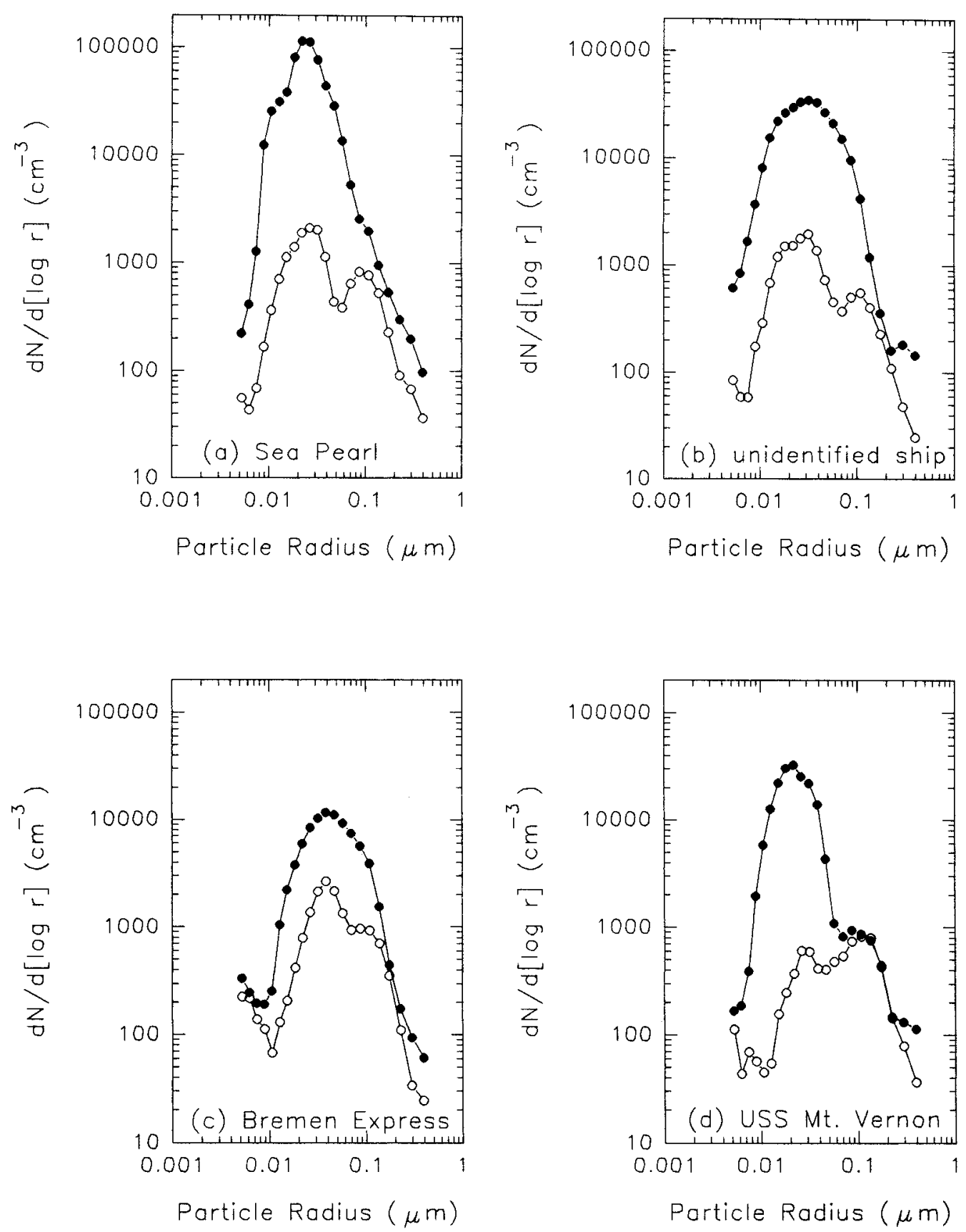

FIG. 6. Particle size spectra measured from the airship in noncloudy air in the plumes from four of the case study ships (closed circles) and in the adjacent ambient air (open circles). The Sea Pearl is diesel powered and used marine fuel oil; the Bremen Express is a steam turbine and used marine fuel oil; and the USS Mt. Vernon is a steam turbine and used navy distillate fuel. All three ships were going with the wind, and the measurements were made 1 and $3 \mathrm{~km}$ from the ships. The unidentified ship was moving into the wind, and the measurements were taken at $9 \mathrm{~km}$ from the ship.

particles in the ambient air is assumed to be any mixture of ammonium sulfate and sulfuric acid provided the mixture is less acidic than ammonium bisulfate (any such mixture will give the same result; Hoppel et al. 1996).

The model is then applied to the aerosol size distri- bution measured in the plume from a ship below cloud base, using the same "effective dynamics" (effective updraft velocity and height) as in the ambient air, to simulate the in-plume cloud microphysics. Unlike the ambient particles, the ship-generated particles are, most likely, composed mostly of insoluble material such as 

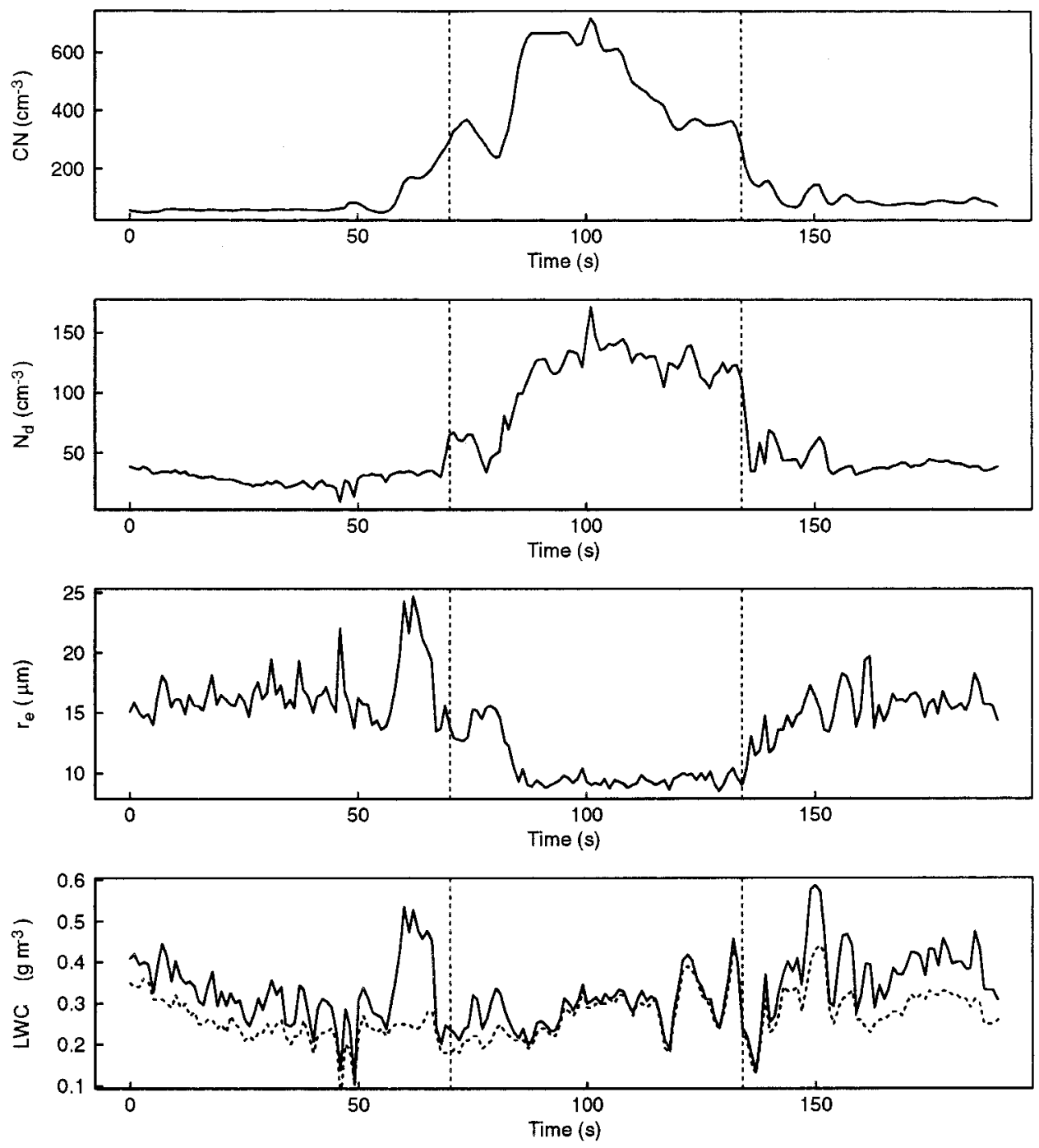

FIG. 7. Measurements from the C-131A of cloud interstitial CN concentrations, droplet concentrations $\left(N_{d}\right)$, effective radii $\left(r_{e}\right)$, cloud LWC (dashed line), and total liquid water contents $\left(\mathrm{LWC}_{\mathrm{tot}}\right.$; solid line) in a transect of an 80-min-old ship track produced by the diesel-powered Star Livorno using marine fuel oil. The region between the vertical dotted lines delineates the ship track defined by the averaging scheme. The $\mathrm{CN}$ concentration measurements are from the TSI 3760 counter; $N_{d}$ measurements are from the PMS FSSP-100; $r_{e}$ measurements are from the PMS FSSP-100 and the PMS OAP-2D-C probe; cloud LWC content measurements are from the Gerber PVM-100; and $\mathrm{LWC}_{\text {tot }}$ measurements are from the sum of the LWCs measured by the Gerber PVM-100 and the PMS 2D-C probes.

soot and fuel-derived ash, possibly coated with more soluble material, such as sulfates. If we assume that the particles generated by the ship are internally mixed particles with the same soluble fraction $(\varepsilon)$, then the relationship between the dry radius $\left(r_{d}\right)$ of the particle and its critical supersaturation $\left(S_{c}\right)$ is given by (Fitzgerald 1973)

$$
S_{c}=\operatorname{constant} /\left(\varepsilon^{1 / 2} r_{d}^{3 / 2}\right) .
$$

If we now define a new radius $r_{s}$ by the expression

$$
r_{s}=\varepsilon^{1 / 3} r_{d},
$$

the totally soluble particles of the smaller radius $r_{s}$ will have the same activation threshold as particles of radius $r_{d}$ with fraction, $\varepsilon$, of soluble material. Therefore, if we shift the (cumulative) size distribution of the ship-generated particles to radius $r_{s}$, we can consider the shifted size distribution as composed of soluble material. Further corrections are made for the fact that the measurements in the DMA were at about 50\% relative humidity, and not at the dry radius. It should be pointed out that the above arguments could all be made in terms of the $\mathrm{CCN}$ supersaturation spectrum by transforming the size distribution to a $\mathrm{CCN}$ supersaturation spectrum using Eq. (4) above.

There were differences in the number of ambient 

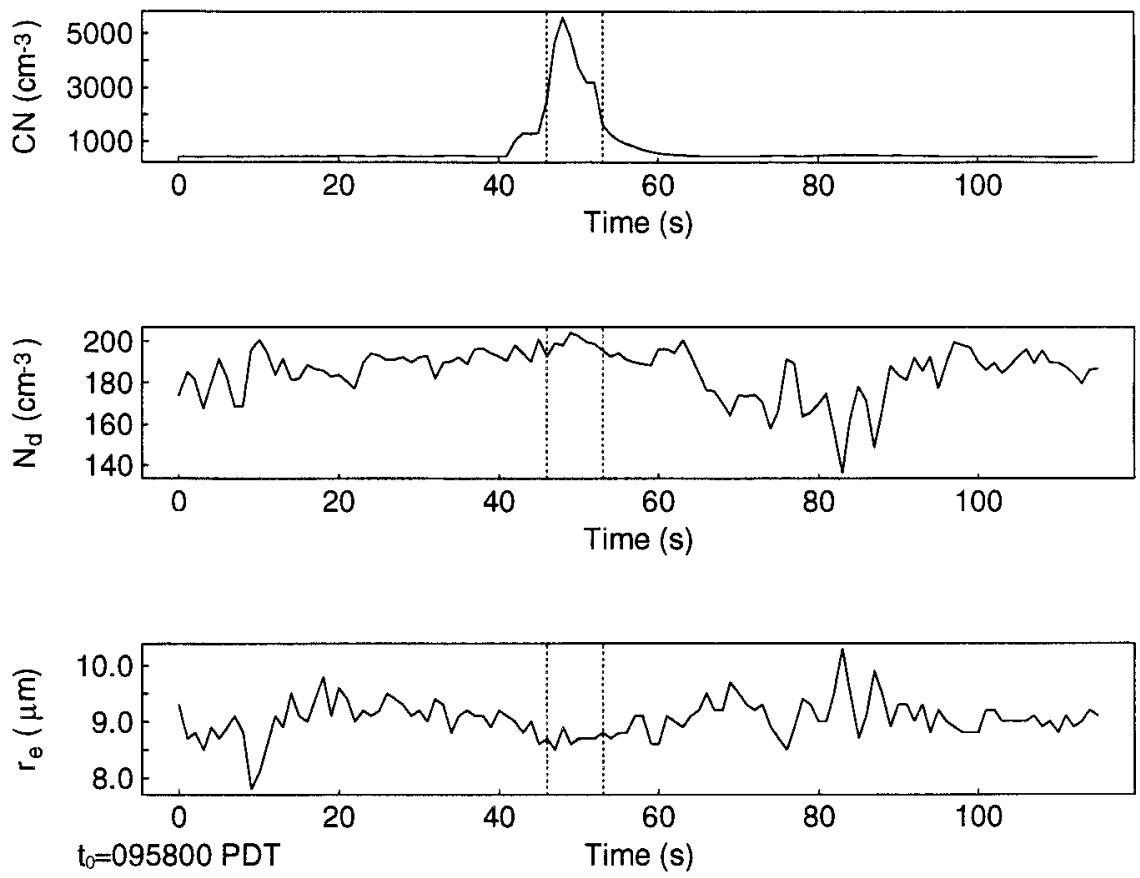

FIG. 8. Measurements from the $\mathrm{C}-131 \mathrm{~A}$ of interstitial $\mathrm{CN}$ concentrations, droplet concentrations $\left(N_{d}\right)$, and effective radii $\left(r_{e}\right)$, in a transect of a ship track produced by the steam turbine-powered USS Mt. Vernon using navy distillate fuel. The region between the dotted lines shows the main region of the ship track. The $\mathrm{CN}$ concentration measurements are from the TSI $3760 ; N_{d}$ measurements are from the PMS FSSP-100; and $r_{e}$ measurements are from the PMS FSSP-100 and the PMS OAP-2D-C probes.

cloud droplets measured with the PMS CSASP-100-HV and the number of particles under the cloud residue mode measured below the background cloud. But since the cloud residue mode was observed to be activated within the clouds, we attributed these modest differences to instrumental differences and normalized the size distribution so that the number of cloud residue particles was equal to the number of cloud droplets.

The procedure was as follows. 1) Generate 42 size bins from the 21 measured by the DMA. This was necessary because the in-plume size distribution can be very steep in the region of interest, and activating one additional channel can produce significant differences in the number of activated particles (cloud droplets) in the case of 21 channel resolution. 2) Normalize the measured size distributions so that the number of particles under the cloud residue mode in the ambient air equaled the number of droplets observed in the cloud. 3) Determine the rate of expansion required to activate all cloud residue mode particles in the ambient air. 4) Determine the duration of the expansion required to produce the observed liquid water cloud in the cloud. 5) Calculate the ship-generated aerosol size distribution by subtracting the ambient size distribution from the inplume size distribution (both measured below cloud). 6) Shift the ship-generated size distribution to smaller sizes to account for the fraction of insoluble material [the shift is given by Eq. (5) above]. 7) Add the shifted (ship's) aerosol size distribution to the ambient size distribution (assumed to be totally soluble material) to obtain the equivalent "activation" size distribution. The resulting size distribution is used as input into the model, together with the predetermined expansion, to calculate the in-plume, cloud microphysics.

The results of such model calculations depend on the soluble fraction $(\varepsilon)$ of material in the ship's particles. Therefore, if $\varepsilon$ is not known, its value can be adjusted to obtain a best fit to the measurements. For example, once the "dynamics" is fixed by running the model on ambient cloud, the model can be run on a ship track for various assigned values of $\varepsilon$ (we took $12 \%, 25 \%$, and $100 \%)$ to see which values yield droplet concentrations $\left(N_{d}\right)$ in a ship track that are closest to the measured concentrations.

A summary of some pertinent results for three dieselpowered ships is given in Table 5. For example, for the Sea Pearl the model calculations for the ship track showed that if the ship-produced particles (with size distribution shown in Fig. 6a) are assumed to be $100 \%$ soluble, the concentration of cloud droplets in the track $\left(492 \mathrm{~cm}^{-3}\right)$ would be much greater than observed (and the effective radius would have been smaller by a factor of 0.82 than was observed). However, if the fraction of soluble material in the particles from the ship is assumed to be $12 \%$, the agreement between the model results and the measurements in the ship track is much better. Had 
TABLE 5. Comparisons of model predictions and measurements of cloud droplet concentrations $\left(N_{d}\right)$ for three diesel-powered ships.

\begin{tabular}{|c|c|c|c|}
\hline \multirow[b]{2}{*}{ Ship } & \multirow[b]{2}{*}{$\begin{array}{c}\text { Ambient air } \\
N_{d} \\
\left(\mathrm{~cm}^{-3}\right)\end{array}$} & \multicolumn{2}{|c|}{ Ship track } \\
\hline & & $\begin{array}{l}\text { Assumed } \\
\text { soluble fraction } \\
\text { of particles } \\
\text { in ship } \\
\text { emissions } \\
(\%)\end{array}$ & $\begin{array}{c}N_{d} \\
\left(\mathrm{~cm}^{-3}\right)\end{array}$ \\
\hline \multicolumn{4}{|l|}{ NYK Sunrise } \\
\hline Observed & 180 & - & $248^{*}$ \\
\hline Modeled & 180 & $\begin{array}{r}12 \\
25 \\
100\end{array}$ & $\begin{array}{l}524 \\
960 \\
831\end{array}$ \\
\hline \multicolumn{4}{|l|}{ Tai He } \\
\hline $\begin{array}{l}\text { Observed } \\
\text { Modeled }\end{array}$ & $\begin{array}{l}150 \\
150\end{array}$ & $\begin{array}{r}\overline{12} \\
25 \\
100\end{array}$ & $\begin{array}{r}300 \\
257 \\
691 \\
1077\end{array}$ \\
\hline \multicolumn{4}{|l|}{ Sea Pearl } \\
\hline $\begin{array}{l}\text { Observed } \\
\text { Modeled }\end{array}$ & $\begin{array}{l}213 \\
215\end{array}$ & $\begin{array}{r}\overline{12} \\
25 \\
100\end{array}$ & $\begin{array}{l}273 \\
303 \\
385 \\
492\end{array}$ \\
\hline
\end{tabular}

* Age of "parcel" was $60 \mathrm{~min}$. Therefore, observed $N_{d}$ is expected to be below modeled value because of dispersion of plume.

the soluble fraction been lowered further, exact agreement could have been obtained. In the case of the Tai $\mathrm{He}$, an assumed soluble fraction of $12 \%$ yielded model values of $N_{d}$ slightly below those measured in the ship track.

For the NYK Sunrise, even a soluble fraction of $12 \%$ gave much greater concentrations of cloud droplets than were measured in the ship track. However, in this case the measurements in the track were made on a 60-minold "parcel," whereas the model calculations apply to a cloud parcel that has not undergone much dispersion downwind.

We conclude from these comparisons of model results with measurements that if the ship tracks produced by diesel-powered ships using marine fuel oil are due entirely to particles from the ships, the particles must consist mostly ( $\sim 90 \%)$ of insoluble material; otherwise the increases in cloud droplet concentrations (and decreases in cloud droplet effective radius) would have been much greater than were measured.

\section{f. Composition of aerosols in ship effluents}

Samples of air beneath cloud base, and cloud interstitial air in cloudy regions intercepted by ship plumes, were collected aboard the $\mathrm{C}-131 \mathrm{~A}$ by rapidly filling a large $\left(2.5 \mathrm{~m}^{3}\right)$ "grab bag" with ram air from an isokinetic inlet during aircraft penetrations of ship plumes. Two types of filter substrates were used to sample aerosols from the grab bag. One type comprised pairs of Teflon filters (one in each pair fitted with a cyclone to

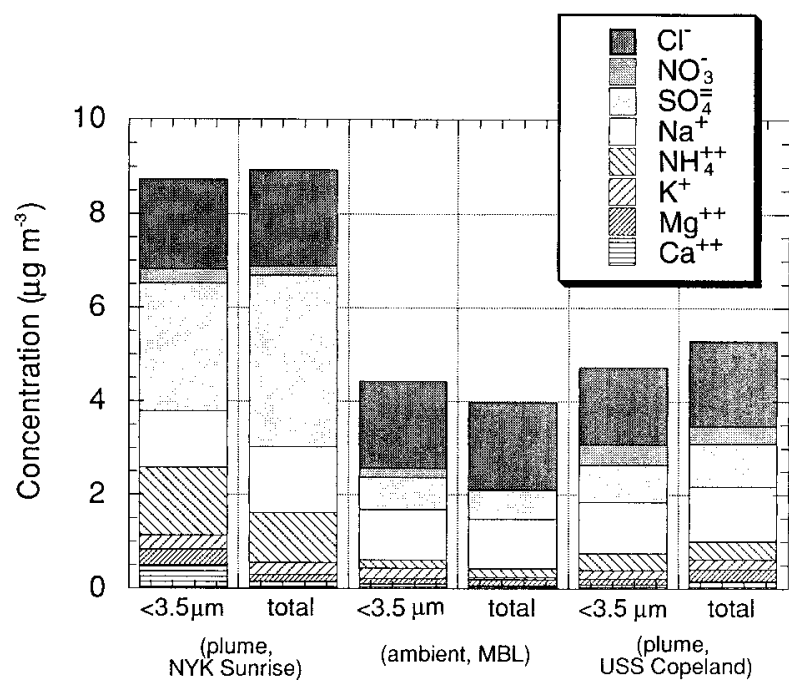

FIG. 9. Concentrations of ionic species measured in ambient air and in the plumes from the diesel-powered NYK Sunrise and the gas turbine-powered USS Copeland using navy distillate fuel.

remove particles $>3.5-\mu \mathrm{m}$ radius, and the other to collect all particles). Subsequently, these filters were extracted and analyzed by ion chromatography (IC) for inorganic anions and cations. The other filters were quartz, which were exposed to aerosols for analysis of organic species (Russell et al. 2000). Plume samples were compared to samples of ambient air to determine if the ships were sources of sulfate, salt, or organic aerosols.

The IC analysis of the Teflon filters showed that of 12 ship plumes sampled, only one (NYK Sunrise) had either sulfate or salt elevated above ambient values within the uncertainty of the measurements. Fig. 9 shows the results for the NYK Sunrise and the USS Copeland, which were sampled on the same flight. The Copeland samples are typical of most of the ship plumes sampled during MAST in that the measured species are not significantly elevated above ambient levels (a possible exception is nitrate, which shows a hint of higher concentrations in the plume). However, the NYK Sunrise exhibits a rather large increase in sulfate $\left(\sim 3-4 \mu \mathrm{g} \mathrm{m}^{-3}\right)$ but not of salt. The cloud interstitial aerosol measurements show that most of the mass of the measured inorganic ions was scavenged by cloud droplets and therefore must reside on particles large enough to be CCN.

Analysis of the quartz filters showed that a number of organic species, typical of diesel emissions, were elevated above ambient levels in both cloud droplets and interstitial aerosol in ship tracks. Although the concentrations were very low, these results confirm that the particles originated in ship exhausts and that some of them may have served as CCN.

Figure 10 shows particle size distributions for various volatility tests measured at distances of $\sim 60-80 \mathrm{~km}$ downwind of the diesel-powered Kurama using marine fuel oil. Two sets of volatility tests were run on both 
plume and ambient air samples. The spectra taken at $150^{\circ}$ and $340^{\circ} \mathrm{C}$ in the plume and ambient air show almost identical characteristics, indicating that the plume aerosol was not composed of sea salt, soot carbon, or ammonium sulfate. The only difference between the plume and ambient aerosol was observed at $40^{\circ} \mathrm{C}$, which suggests that the plume aerosols were composed of sulfuric acid and/or organic material.

The results of these various analyses rule out sulfate, sea salt, and soot carbon as major components of the particles emitted by diesel-powered ships using marine fuel oil. The quartz filter and volatility results are consistent in suggesting that most of the particles were composed of organic materials with high boiling points, possibly combined with some sulfuric acid produced by recent gas-to-particle conversion of $\mathrm{SO}_{2}$.

\section{g. Emissions of heat and water vapor by ships}

Estimates of fluxes of heat through the stacks of the ships studied are given in the last column of Table 2, with a footnote stating how these fluxes were estimated. The fluxes range from $\sim 2$ to $22 \mathrm{MW}$.

Moisture fluxes can be estimated from Eq. (1), since this shows that $1.17 \mathrm{~kg}$ of water is produced for every kilogram of fuel burned. These fluxes, which are listed in Table 3, range from 0.4 to $1.5 \mathrm{~kg} \mathrm{~s}^{-1}$. When water fluxes of these amounts are diluted into a region with a cross-sectional area equal to a ship's plume or a ship track, their effects should be negligible.

The C-130 flew as low as possible (within $100 \mathrm{~m}$ of the ocean surface on occasions) through the visible plumes from a number of ships to try to detect heat and moisture emissions. It was extremely rare that any significant temperature perturbation was found to be associated with the emissions from a ship, and on no occasion was a perturbation in water vapor discernible. On just four occasions the penetration of the plume from a ship was accompanied by a measurable increase in temperature, and these all occurred within $150 \mathrm{~m}$ of the ship. At greater distances downwind from these same ships no detectable thermal signatures were measured. This suggests that mixing of the plumes from the ships with ambient air was very rapid. The plumes had no detectable buoyancy, even as close as $\sim 200 \mathrm{~m}$ from the ships.

The best example of measurable heat release from a ship was on 21 June for the Cape May. This ship was steaming at almost the same velocity as the wind in the lower part of the boundary layer, so the emissions from the ship were present in relatively high concentrations. There was a wind shear in the boundary layer, and above about $100 \mathrm{~m}$ the wind speed increased sufficiently for the plume to be advected ahead of the ship. Figure 11 shows a time series of a run at 150 -m altitude that passed over the ship in the direction of motion of the ship. The plume was encountered at 2133:40 UTC almost directly over the top of the ship, where a maximum was observed
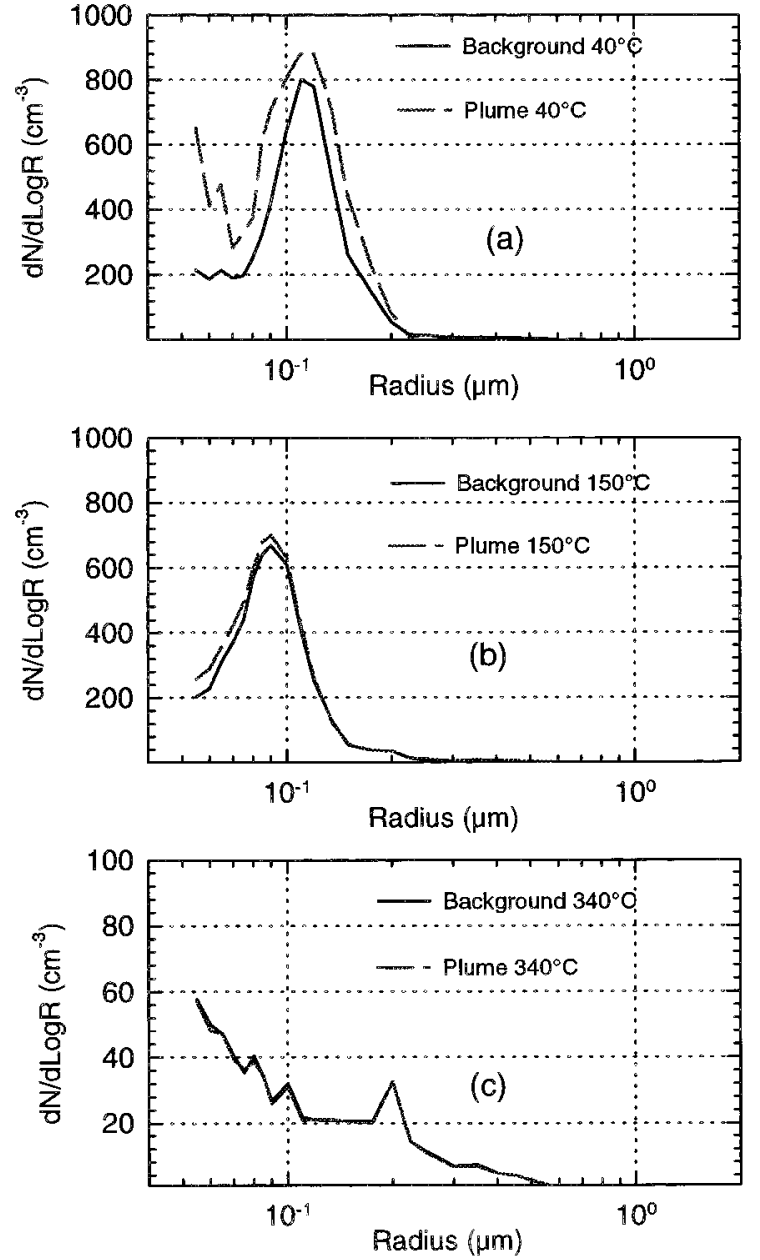

FIG. 10. Particle size spectra measured from the C-130 in ambient air and at an altitude of $152 \mathrm{~m}$ in the plume from the Kurama powered by marine fuel oil. The particles were subjected to three temperatures ( $T$ ) before the spectra were measured: (a) $T=40^{\circ}$, (b) $T=150^{\circ}$, and (c) $T=340^{\circ} \mathrm{C}$.

in the concentration of accumulation-mode aerosols $\left(14000 \mathrm{~cm}^{-3}\right)$ and the potential temperature briefly increased by about $0.4^{\circ} \mathrm{C}$. Based on a nearby profile measured from the aircraft, and assuming no mixing with the ambient air, this temperature excess would have been sufficient to lift the plume a further 75 to $225 \mathrm{~m}$ (about the middle of the boundary layer). No temperature excess was observed farther downwind in the plume. As in all other plume penetrations during MAST, the incloud temperature sensor gave no indication of a temperature increase. The temperature probe averaged over relatively large distances compared to the width of the plume, so that any thermal signature from the plume was lost for a narrow plume. It can be concluded that the volume of air heated by emissions from the ship was relatively small. Therefore, it is not surprising that heat emissions from ships are quickly diluted.

Figure 11 also shows a typical example of the variation of the water vapor content encountered in the 

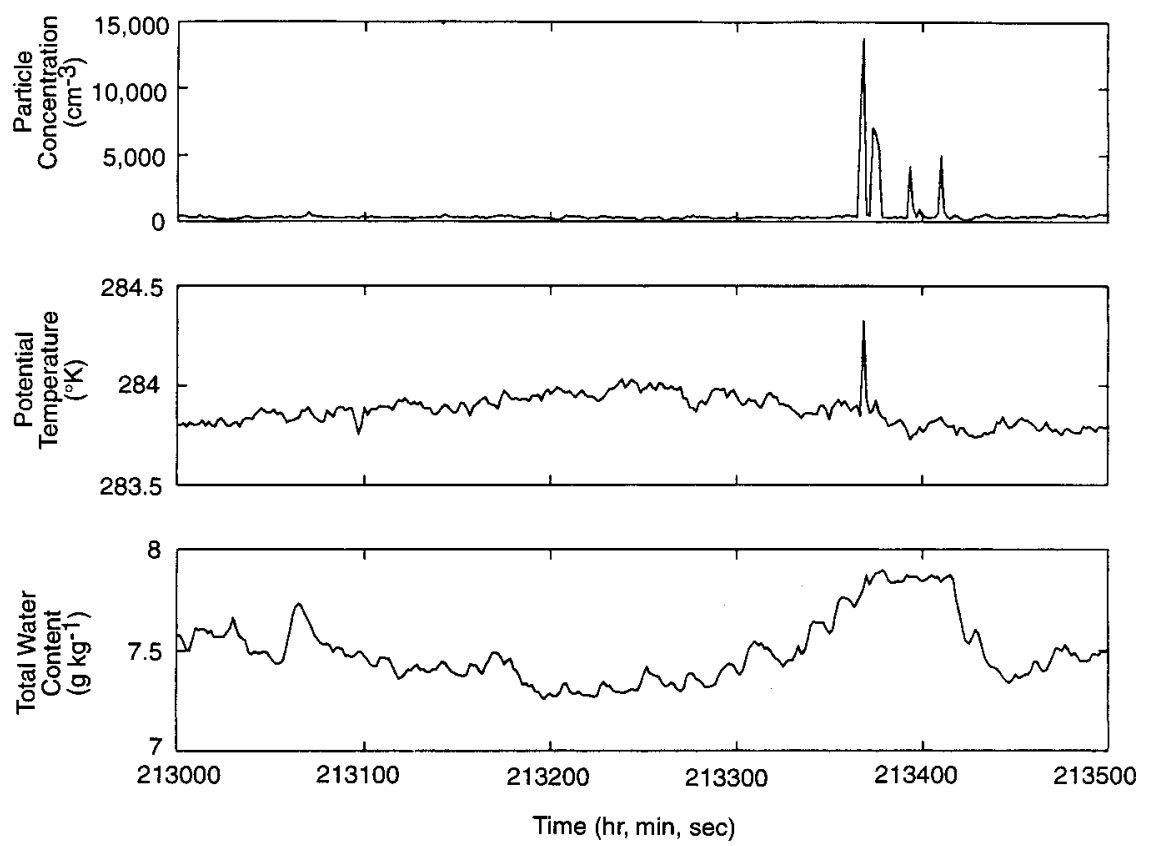

FIG. 11. Measurements of concentration of accumulation-mode aerosol, potential temperature, and total water content obtained on 21 Jun 1994 in a C-130 pass through the plume from the diesel-powered Cape May burning marine fuel oil. The measurements were made at $150 \mathrm{~m}$ directly above the ship.

boundary layer during MAST. There is no indication that the ship emitted significant amounts of water vapor compared with natural variations in the boundary layer.

Other instances of potential temperature perturbations related to plume penetrations close to ships were less marked. On 11 June two penetrations of the plume at $150 \mathrm{~m}$ over the Brazilian Vitoria showed maximum potential temperature increases of $0.2^{\circ}$ and $0.15^{\circ} \mathrm{C}$ at 2054: 57 and 2059:01 UTC, respectively. Also on 9 June a penetration of the plume at $100 \mathrm{~m}$ over the Evergreen Evergather showed a potential temperature increase of $0.1^{\circ} \mathrm{C}$. Although this temperature change was well correlated with increases in aerosol concentrations, it was also very close to ambient temperature variations.

The rarity with which temperature and water vapor increases were found in ship plumes is indicative that heat and water vapor emissions from ships have insignificant effects on boundary layer dynamics and cloud microphysics, and therefore on ship tracks.

\section{Effects of engines and fuels on ship track formation}

Previous experimental studies (Radke et al. 1989; Ferek et al. 1998), as well as those reported in this special issue (e.g., Ferek et al. 2000; Noone et al. 2000a,b; Taylor et al. 2000), show that, under appropriately clean ambient conditions, ship tracks are produced by particles from ships. This conclusion is supported by modeling studies (Ackerman et al. 1995). However, an outstanding question is, why under the same ambient con- ditions do some ships produce ship tracks while others do not? Data collected in the MAST study, some of which have been presented in this paper, shed light on this question, although they do not provide a definitive answer.

If particle emissions are responsible for ship tracks, it might be expected that, for the same ambient conditions, a ship powered by a given type of engine (diesel, steam turbine, or gas turbine) burning a low-grade fuel (such as marine fuel oil) would be more likely to produce ship tracks than if the ship were burning a highgrade distillate fuel. This is because, as discussed in sections 4 and 6, engines burning marine fuel oil emit copious numbers of particles large enough to serve as $\mathrm{CCN}$. The range of ambient cloud droplet concentrations observed in MAST for which diesel-powered ships burning marine fuel oil produced ship tracks in satellite imagery was $12-250 \mathrm{~cm}^{-3}$.

On two occasions (12 and 13 June) in MAST the USS Safeguard, a diesel-powered ship burning navy distillate fuel, produced ship tracks, albeit in very clean conditions (ambient cloud droplet concentrations on 12 and 13 June were 40 and $12 \mathrm{~cm}^{-3}$, respectively). Unfortunately, no measurements were obtained on the size spectra of particles produced by the USS Safeguard. However, from the fact that it produced a ship track, we can surmise that the USS Safeguard emitted adequate numbers of CCN to produce a significant perturbation in the concentrations of drops in the clean clouds that were present on 12 and 13 June. It is not known whether 
emissions from a diesel-powered ship burning navy distillate fuel would be adequate to produce a ship track under the more polluted ambient conditions (up to 250 $\mathrm{cm}^{-3}$ droplets in ambient clouds) for which diesel-powered ships burning marine fuel oil were observed to produce ship tracks.

Neither of the two navy vessels with steam turbine engines that burned navy distillate fuel that were studied in MAST (USS Mt. Vernon and USS Kansas City) produced a ship track. As shown in Figs. 4, 5, and 6, the USS Mt. Vernon emitted smaller particles than dieselpowered ships burning marine fuel oil, and it emitted very few particles larger than $0.05-\mu \mathrm{m}$ radius. Hence, if the emissions from the USS Mt. Vernon are characteristic of those from steam turbine engines burning navy distillate fuel, such ships should be less effective in producing ship tracks than diesel-powered ships burning marine fuel oil. It should be noted, however, that in MAST both the USS Mt. Vernon and the USS Kansas City were investigated under ambient conditions that were not particularly clean (ambient droplet concentrations $>150 \mathrm{~cm}^{-3}$ ). It is not known whether emissions from steam (or gas) turbine-powered ships burning navy distillate fuel can produce ship tracks in very clean ambient conditions.

The gas turbine-powered USS Copeland, burning navy distillate fuel, produced particle emissions with a mode size similar to that of the USS Mt. Vernon $(\sim 0.02-$ $\mu \mathrm{m}$ radius). There is no evidence that the USS Copeland produced a ship track.

There is ample evidence that commercial steam turbine-powered ships, fueled by marine fuel oil, can produce ship tracks (e.g., at least 13 such ships were observed to produce ship tracks on satellite imagery during MAST). However, in situ measurements were obtained on only one such ship (Bremen Express) in MAST. The size spectra of particles measured in the emissions from this ship have a mode radius of $\sim 0.04 \mu \mathrm{m}$ (Fig. 6c), which is similar to that for diesel-powered ships burning marine fuel oil (e.g., Fig. 4e). This supports our suggestion that fuel type, rather than engine type, is more important in determining the size distribution of particles emitted, and therefore whether or not a ship has a high a potential for producing a ship track. On the day the Bremen Express was observed (28 June) it did not, in fact, produce a ship track. However, the concentration of drops in the ambient clouds was relatively high (230 $\mathrm{cm}^{-3}$ ). Under cleaner conditions, we would expect the Bremen Express to produce a ship track.

The available information supports the hypothesis that, for the same ambient cloud conditions, ships burning low-grade fuels (such as marine fuel oil) are more likely to produce ship tracks than ships burning highergrade distillate fuels, with, perhaps, engine type playing a secondary role. However, definitive tests of this hypothesis need to address the following questions.

1) Can ships with steam (or gas) turbine engines burn- ing navy distillate fuel produce ship tracks in a clean environment (e.g., one in which the ambient cloud drop concentration is considerably less than 150 $\left.\mathrm{cm}^{-3}\right)$ ?

2) Can ships with diesel engines burning navy distillate fuel produce ship tracks in clouds with ambient droplet concentrations much greater than the $40 \mathrm{~cm}^{-3}$ in which the USS Safeguard produced a ship track in MAST?

\section{Summary and conclusions}

In this paper information has been presented on the ships studied in MAST, and in situ airborne measurements from several platforms have been used to determine the nature of the emissions from these ships, with emphasis on particle emissions.

Emission factors of $\mathrm{SO}_{2}$ and $\mathrm{NO}$ for diesel-powered and steam turbine-powered ships burning low-grade marine fuel oil (derived from airborne measurements using the carbon dioxide balance technique) ranged from 15 to 89 and from 2 to $25 \mathrm{~g} \mathrm{~kg}^{-1}$ of fuel burned, respectively. By contrast, a steam turbine-powered ship burning high-grade navy distillate fuel, emitted only 6 $\mathrm{g} \mathrm{kg}^{-1}$ of $\mathrm{SO}_{2}$. The derived fluxes of $\mathrm{SO}_{2}$ and $\mathrm{NO}$ from the diesel- and steam turbine-powered ships burning marine fuel oil were 15-41 and 1-18 $\mathrm{g} \mathrm{s}^{-1}$, respectively. For the steam turbine-powered ship burning navy distillate fuel the flux of $\mathrm{SO}_{2}$ ranged from 1.7 to $6.8 \mathrm{~g} \mathrm{~s}^{-1}$ for two days with different fuel consumption rates.

Diesel-powered and steam turbine-powered ships burning marine fuel oil and navy distillate fuels emitted from $\sim 4 \times 10^{15}$ to $2 \times 10^{16}$ total particles per kilogram of fuel burned $\left(\sim 4 \times 10^{15}-1.5 \times 10^{16}\right.$ total particles per second). Most of the particles emitted by the ships were $<0.1 \mu \mathrm{m}$ in radius, with peak concentrations between $\sim 0.01$ - and $0.1-\mu \mathrm{m}$ radius. However, diesel-powered ships burning marine fuel oil emitted particles with a larger mode radius $(\sim 0.03-0.05 \mu \mathrm{m})$ and larger maximum sizes than those powered by steam turbines burning a distillate fuel (mode radius $\sim 0.02 \mu \mathrm{m}$ ). Consequently, for similar chemical compositions, the particles emitted by the former ships will serve as $\mathrm{CCN}$ at lower supersaturations than those emitted by the latter ships. Since steam turbine-powered ships fueled by marine fuel oil emit particles with a mode radius similar to that of diesel-powered ships fueled by marine fuel oil, it appears that fuel type (rather than engine type) is the dominant factor in determining particle emissions.

Measurements in the plumes of emissions from ships show that the mass concentrations of ionic species are generally not significantly elevated above ambient concentrations, presumably because of the small sizes of the particles in ship plumes. However, organic species typical of diesel emissions are elevated above ambient. Volatility measurements on plume samples show that the particles in ship emissions are not composed of sea salt, soot carbon, or ammonium sulfate. It is likely that 
they are composed of organic materials (with high boiling points), possibly combined with sulfuric acid produced by gas-to-particle conversion of $\mathrm{SO}_{2}$ in ship plumes.

Increases in particle concentrations in noncloudy air, produced by emissions from ships, were compared with above-ambient concentrations of cloud droplets and interstitial particles in regions of stratiform cloud affected by ship effluents. These comparisons show that, for diesel-powered ships powered by marine fuel oil, the percentages of particles emitted that serve as $\mathrm{CCN}$ in marine stratiform clouds ranged from $4 \%$ to $18 \%$.

Cloud models applied to observations of the minimum-sized particles in ship effluents that were observed to serve as $\mathrm{CCN}$ suggest that the mass of water-soluble material in a typical particle from a ship is about $10 \%$. This explains why, even for diesel-powered ships using marine fuel oil, only a small fraction of the emitted particles serve as $\mathrm{CCN}$ in marine stratiform clouds, since the particles have to be relatively large to act as CCN if they are composed of about $90 \%$ insoluble materials. Nevertheless, observations of ship emissions and their effects on cloud droplet concentrations reported here are consistent with the hypothesis that particle emissions from ships are responsible for ship tracks. This hypothesis is considered in detail by Durkee et al. (2000).

From engine and fuel combustion data, we have estimated that the fluxes of heat and water vapor from the ships studied in MAST are $\sim 2-22 \mathrm{MW}$ and $0.5-1.5 \mathrm{~kg}$ $\mathrm{s}^{-1}$, respectively. Very rarely were any temperature perturbations measured in the plumes from ships, and no perturbations in water vapor were detected, even very close to the ships. This is strong evidence that heat and water vapor emissions from ships do not play a role in ship track formation. Modeling studies presented in this special issue support this view.

Results presented in this paper suggest that, for the same ambient conditions, ships burning low-grade fuels (such as marine fuel oil) are more likely to produce ship tracks than ships burning higher-grade distillate fuels, with engine type playing a secondary role in this respect. This is attributable to the particles emitted from lowgrade fuels being more efficient $\mathrm{CCN}$ than those emitted from higher-grade fuels. To further test this hypothesis, more measurements are needed on ships with different engines, powered by different fuels and, most important, in a wide variety of ambient cloud conditions.

Acknowledgments. This research was supported by the Department of the Navy, Office of the Chief of Naval Research, under Grants N00014-92-J-1587, N0001493-1-0872, and N00014-94-1-0663. The views presented here do not necessarily reflect those of the U.S. Government.

\section{REFERENCES}

Ackerman, A. S., O. B. Toon, and P. V. Hobbs, 1995: Numerical modeling of ship tracks produced by injections of cloud con- densation nuclei into marine strafiform clouds. J. Geophys. Res., 100, 7212-7133.

Baumgardner, D., 1982: A description of FSSP auxiliary variables and their use. NCAR Tech. Note 199, $103 \mathrm{pp}$.

— and M. Spowart, 1990: Evaluation of the Forward Scattering Spectrometer Probe. Part III: Time response and laser inhomogeneity limitations. J. Atmos. Oceanic Technol., 7, 666-672.

Durkee, P. A., and Coauthors, 2000: The impact of ship-produced aerosols on the microstructure and albedo of warm marine stratocumulus clouds: A test of MAST hypotheses 1i and 1ii. $J$. Atmos. Sci., 57, 2554-2569.

Eagan, R. C., P. V. Hobbs, and L. F. Radke, 1974: Particle emissions from a large Kraft paper mill and their effects on the microstructure of warm clouds. J. Appl. Meteor., 13, 535-552.

Enga, B. E., M. F. Buchman, and I. E. Lichtenstein, 1982: Catalytic control of diesel particulates. Society of Automotive Engineers Tech. Paper 820184, 30 pp. [Available from Society of Automotive Engineers World Headquarters, 400 Commonwealth Dr., Warrendale, PA 15086.]

Ferek, R. J., D. A. Hegg, P. V. Hobbs, P. Durkee, and K. Nielsen, 1998: Measurements of ship-induced tracks in clouds off the Washington coast. J. Geophys. Res., 103, 23 199-23 206.

- , and Coauthors, 2000: Drizzle suppression in ship tracks. $J$. Atmos. Sci., 57, 2707-2728.

Fitzgerald, J. W., 1973: Dependence of the supersaturation spectrum of CCN on aerosol size distribution and composition. J. Atmos. Sci., 30, 628-634.

Frick, G. M., and W. A. Hoppel, 1993: Airship measurements of aerosol size distributions, cloud droplet spectra, and trace gas concentrations in the marine boundary layer. Bull. Amer. Meteor. Soc., 74, 2195-2202.

- , and - 2000: Airship measurements of ship's exhaust plumes and their effect on marine boundary layer clouds. J. Atmos. Sci., 57, 2625-2648.

Frisbie, P. R., and J. G. Hudson, 1993: Urban cloud condensation nuclei spectral flux. J. Appl. Meteor., 32, 666-676.

Garrett, T. J., and P. V. Hobbs, 1995: Long-range transport of continental aerosols over the Atlantic Ocean and their effects on cloud structures. J. Atmos. Sci., 52, 2977-2984.

Gerber, H., B. G. Arends, and A. S. Ackerman, 1994: New microphysics sensor for aircraft use. Atmos. Res., 31, 235-252.

Hallett, J., J. G. Hudson, and C. F. Rogers, 1989: Characterization of combustion aerosols for haze and cloud formation. Aerosol Sci. Technol., 10, 70-83.

Hegg, D. A., D. S. Covert, M. J. Rood, and P. V. Hobbs, 1996: Measurements of aerosol optical properties in marine air. J. Geophys. Res., 101, 12 893-12 903.

Hobbs, P. V., L. F. Radke, and S. E. Shumway, 1970: Cloud condensation nuclei from industrial sources and their apparent influence on precipitation in Washington State. J. Atmos. Sci., 27, 81-89.

- J. L. Stith, and L. F. Radke, 1980: Cloud-active nuclei from coal-fired electric power plants and their interactions with clouds. J. Appl. Meteor., 19, 439-451.

— L. F. Radke, J. H. Lyons, R. J. Ferek, D. J. Coffman, and T. J. Casadevall, 1991: Airborne measurements of particle and gas emissions from the 1990 volcanic eruptions of Mount Redoubt. J. Geophys. Res., 96, 18 735-18 752.

Hoppel, W. A., G. M. Frick, and R. E. Larson, 1986: Effect of nonprecipitating clouds on the aerosol size distribution in the marine boundary layer. Geophys. Res. Lett., 13, 125-128.

_ J. W. Fitzgerald, G. M. Frick, R. E. Lason, and E. J. Mack, 1990: Aerosol size distributions and optical properties found in the marine boundary layer over the Atlantic Ocean. J. Geophys. Res., 95, 3659-3686.

—, G. M. Frick, and J. W. Fitzgerald, 1996: Deducing droplet concentration and supersaturation in marine boundary layer clouds from surface aerosol measurements. J. Geophys. Res., 101, 26 553-26565.

Johnson, J. H., W. H. Lipkea, and C. T. Vuk, 1978: The physical and chemical character of diesel particulate emission-Measurement 
techniques and fundamental considerations. Society of Automotive Engineers Tech. Paper 789108, 13 pp. [Available from Society of Automotive Engineers World Headquarters, 400 Commonwealth Dr., Warrendale, PA 15086.]

Mossop, S. C., 1983: Intercomparison of instruments used for measurement of cloud drop concentration and size distribution. $J$. Climate Appl. Meteor., 22, 419-428.

Noone, K. J., and Coauthors, 2000a: A case study of ship track formation in a polluted marine boundary layer. J. Atmos. Sci., 57, 2748-2764.

- , and Coauthors, 2000b: A case study of ships forming and not forming tracks in moderately polluted clouds. J. Atmos. Sci., 57, 2729-2747.

O’Dowd, C. D., and M. H. Smith, 1993: Physicochemical properties of aerosols over the Northeast Atlantic: Evidence for windspeed-related submicron sea-salt aerosol production. J. Geophys. Res., 98, 1137-1149.

Radke, L. F., J. A. Coakley Jr., and M. D. King, 1989: Direct and remote sensing observations of the effects of ships on clouds. Science, 246, 1146-1149.
Rogers, D. P., D. W. Johnson, and C. A. Friehe, 1995: The stable internal boundary layer over a coastal sea. Part II: Gravity waves and the momentum balance. J. Atmos. Sci., 52, 684-696.

Russell, L. M., S.-H. Zhang, R. C. Flagan, and J. H. Seinfeld, 1996: Radially classified aerosol detector for aircraft-based submicron aerosol measurements. J. Atmos. Oceanic Technol., 13, 598-609.

- K. J. Noone, R. J. Ferek, R. A. Pockalny, R. C. Flagan, and J. H. Seinfeld, 2000: Combustion organic aerosol as cloud condensation nuclei in ship tracks. J. Atmos. Sci., 57, 2591-2606.

Taylor, J. P., M. D. Glew, J. A. Coakley Jr., W. R. Tahnk, S. Platnick, P. V. Hobbs, and R. J. Ferek, 2000: Effects of aerosols on the radiative properties of clouds. J. Atmos. Sci., 57, 2656-2670.

Tessmer, S., 1996: Analysis of ship track persistence with in situ cloud measurements and satellite retrieved reflectance. M.S. thesis, Dept. of Meteorology, Naval Postgraduate School, 60 pp. [Available from Department of Meteorology, Naval Postgraduate School, 589 Dyer Rd., Monterey, CA 93943-5114.]

Tuttle, K. L., 1995: Combustion-generated emissions in marine propulsion systems. Proc. SNAME 1994 Environmental Symp.Ship Design and Operation in Harmony with the Environment, Jersey City, NJ, SNAME, 311-323. 